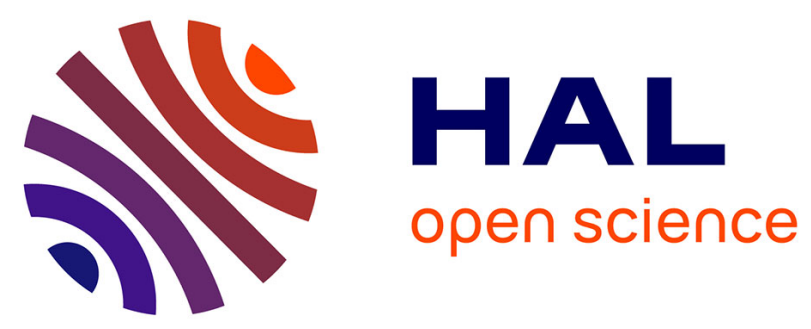

\title{
The eruptive chronology of the Yucamane-Calientes compound volcano: A potentially active edifice of the Central Andes (southern Peru)
}

Marco Rivera, Pablo Samaniego, Jessica Vela, Jean-Luc Le Pennec, Hervé Guillou, Jean-Louis Paquette, Céline C. Liorzou

\section{To cite this version:}

Marco Rivera, Pablo Samaniego, Jessica Vela, Jean-Luc Le Pennec, Hervé Guillou, et al.. The eruptive chronology of the Yucamane-Calientes compound volcano: A potentially active edifice of the Central Andes (southern Peru). Journal of Volcanology and Geothermal Research, 2020, 393, pp.106787. 10.1016/j.jvolgeores.2020.106787 . hal-02529338

\section{HAL Id: hal-02529338 \\ https://hal.uca.fr/hal-02529338}

Submitted on 12 Nov 2020

HAL is a multi-disciplinary open access archive for the deposit and dissemination of scientific research documents, whether they are published or not. The documents may come from teaching and research institutions in France or abroad, or from public or private research centers.
L'archive ouverte pluridisciplinaire HAL, est destinée au dépôt et à la diffusion de documents scientifiques de niveau recherche, publiés ou non, émanant des établissements d'enseignement et de recherche français ou étrangers, des laboratoires publics ou privés. 


\title{
The eruptive chronology of the Yucamane-Calientes compound volcano:
} a potentially active edifice of the Central Andes (southern Peru)

\author{
Marco Rivera ${ }^{1 *}$, Pablo Samaniego ${ }^{2}$, Jessica Vela ${ }^{1}$, Jean-Luc Le Pennec², \\ Hervé Guillou ${ }^{3}$, Jean-Louis Paquette ${ }^{2}$, Céline Liorzou ${ }^{4}$
}

${ }^{1}$ Observatorio Vulcanológico del INGEMMET, Dirección de Geología Ambiental y Riesgo Geológico, Urb. Magisterial B-16, Umacollo, Arequipa, Peru

${ }^{2}$ Université Clermont Auvergne, CNRS, IRD, OPGC, Laboratoire Magmas et Volcans, F63000 Clermont-Ferrand, France

${ }^{3}$ Laboratoire des Sciences du Climat et de l'Environnement, LSCE/IPSL, CEA-CNRS-UVSQ, Université Paris-Saclay, F-91198 Gif-sur-Yvette, France

${ }^{4}$ Laboratoire Géosciences Océan, Institut Universitaire Européen de la Mer, Université de Bretagne Occidentale, Rue Dumont d'Urville, 29280 Plouzané, France

* Now at Instituto Geofísico del Perú, Observatorio Vulcanológico del Sur, Mz B, Lt 19, Urb. La Marina, Cayma, Arequipa, Peru

Corresponding author: mrivera@igp.gob.pe

\section{Abstract}

We reconstruct the eruptive chronology of the Yucamane-Calientes compound volcano in southern Peru based on extensive fieldwork and a large dataset of geochronological (K-Ar, ${ }^{40} \mathrm{Ar} /{ }^{39} \mathrm{Ar}$, U-Pb, and ${ }^{14} \mathrm{C}$ ) and geochemical (major and trace element) analyses. This compound volcano is composed of two edifices that have experienced discontinuous volcanic activity from the middle Pleistocene to the Holocene. The Calientes volcano has been constructed in four successive stages: Calientes I is composed of andesitic lava flows dated at $\sim 500$ ka. Subsequently, the Callazas ignimbrite (Calientes II stage) was emplaced 160-190 ka, followed by the main cone-building stage (Calientes III) at 130-100 ka. Finally, the Holocene Calientes domes were emplaced and represent the last eruptive products of this edifice. The Yucamane volcano has been constructed in three stages: Yucamane I consists of a succession of andesitic lava flows exposed at the base of the volcano that are older than 40 ka. Yucamane II ( 36-30 ka) comprises a thick sequence of block-and-ash-flow deposits that represents an episode of dome growth predating the younger Yucamane cone (Yucamane III) 
built after 20-25 ka. During the Holocene, Yucamane vulcanian to sub-Plinian activity has emplaced tephra-fall and pyroclastic-density-current deposits. The most recent explosive eruptions occurred $c a$. $3000 \mathrm{BP}$ and emplaced a tephra-fall and pumice-flow deposits. Most samples from Calientes volcano are andesites and dacites (60.1-67.7 wt.\% $\mathrm{SiO}_{2}$ ), while rocks from Yucamane volcano are basaltic-andesites to dacites (53.4-66.9 wt.\% $\mathrm{SiO}_{2}$ ). The rocks have a mineral assemblage of plagioclase, amphibole, biotite, orthopyroxene, clinopyroxene, olivine, and Fe-Ti oxides. The analyzed samples are categorized within a high-K, calcalkaline series. Calientes volcano erupted mostly andesitic magmas, but its history is punctuated by rare eruptions of silica-rich magmas. In contrast, Yucamane volcano follows a different trend characterized by a gradual decrease in silica content through post-glacial time, from the large (VEI 3) sub-Plinian andesitic eruption of $\sim 3$ ka to moderate fyEI vulcanian eruptions of basaltic-andesitic. On the basis of such recurrent and recent (Holocene), low-to-moderate explosive activity, Yucamane must be considered an active and potentially threatening volcano, which may affect the province of Candarave with $~ 8,000$ inhabitants.

Keywords: Calientes, Yucamane, Central Andes, Holocene, eruptive chronology, volcanic hazards

\section{Introduction}

The Central Volcanic Zone (CVZ) of the Andes extends from $16^{\circ} \mathrm{S}$ (Southern Peru) to $28^{\circ} \mathrm{S}$ (Northern Chile), and mainly consists of sparse large rhyolitic calderas and many Pliocene-Quaternary, andesitic-to-dacitic composite volcanoes (de Silva and Francis, 1991; Sébrier and Soler, 1991; Stern, 2004; Mamani et al., 2010; Thouret et al., 2016). The Peruvian segment of the CVZ comprises at least 14 Quaternary volcanic centers and several monogenetic fields (Siebert et al., 2010) (Fig. 1a, b). Large explosive eruptions have occurred in this arc segment during the late Holocene and historically, including the last Plinian eruptions of El Misti (c. 2030 yBP, Thouret et al., 2001; Harpel et al., 2011; Cobeñas et al., 2012), Ubinas (c. 1000 yBP, Thouret et al., 2005), and Huaynaputina (1600 CE, Thouret et al., 2002), as well as the collapse-triggered, explosive eruption of Tutupaca (1787-1802 CE, Samaniego et al., 2015). In addition, Ubinas and Sabancaya are among the most active Central Andean volcanoes, with several periods each of eruptive activity with events of volcanic explosivity index (VEI) 1-2 during the last centuries. The most recent such eruptions occurred during 2006-2009 CE and 2013-2017 CE at Ubinas and 1990-1998 CE at 
Sabancaya. In addition, these two volcanoes display on-going eruptions that began in 2015 $C E$ at Sabancaya and $2019 C E$ at Ubinas.

Reconstructing the eruptive chronology of a potentially active volcano represents a key step for hazard assessment. During the last decades, the eruptive chronologies of El Misti (Thouret et al., 2001), Ubinas (Thouret et al., 2005), and Ampato-Sabancaya (Samaniego et al., 2016) have been investigated in detail. However, little is known about other volcanic centers such as Yucamane-Calientes (Rivera and Mariño, 2004), a young-looking edifice located 7-8 km NE of Candarave in Tacna Province, southern Peru (Fig. 1b, c). The volcano is situated on a gently inclined plateau, bounded by the Calientes and Callazas rivers to the east and west, respectively. Small villages on this plateau are located at 8 to $20 \mathrm{~km}$ south of Yucamane's summit (Fig. 1). The total population living in a radius of $20 \mathrm{~km}$ of this volcanic center is roughly estimated at 8,000 inhabitants (INEI, 2018).

We undertook a comprehensive volcanological study of the Yucamane-Calientes, including detailed fieldwork coupled with geochronological and geochemical analyses to reconstruct the structure and eruptive chronology of this compound volcano from the Middle Pleistocene to Holocene. Based on these data, we propose that Yucamane-Calientes consists of two adjacent edifices with contrasting morphologies and eruptive styles, both active through the Holocene.

\section{Geological setting}

The Yucamane-Calientes compound volcano (YCCV, $15^{\circ} 49.3^{\prime} \mathrm{S}, 71^{\circ} 52.7^{\prime} \mathrm{W}$ ) is constructed on the Mesozoic and Cenozoic volcanic and sedimentary formations that compose the Western Cordillera of the Peruvian Andes (Sébrier and Soler, 1991). At the latitude of the YCCV, the cordillera is made of Jurassic to Cretaceous sandstones and carbonaceous shales of the Labra and Hualhuani Formations covered by the Toquepala Formation, a Cretaceous volcanic sequence (De la Cruz and De la Cruz, 2000). Overlying these units are the volcanic and volcano-sedimentary sequences of the Tacaza Group and the Huaylillas Formation. Regional studies propose ages in the range of 30-24 Ma for the Tacaza Group (Mamani et al., 2010; Thouret et al., 2016), whereas in the region of the YCCV, the ignimbrites of the Huaylillas Formation have been dated by the K-Ar method at 24-10 Ma (Tosdal et al., 1981; Quang et al., 2005). At the top of the sequence, several eroded composite cones belonging to the Barroso Group (10-1 Ma, Mamani et al., 2010) are exposed near the YCCV, including Nazaparco, San Pedro, and Lopez Extraña volcanoes (Fig. 2). A lava sample from the 
Nazaparco volcano yielded a whole-rock K-Ar age of 5.6 \pm 0.2 Ma (Martínez and Cervantes, 2003).

Two major fault systems cross this part of the Andean cordillera. The main system is a series of NW-SE-trending normal faults with a sinistral component that are roughly parallel to the Andean front (Martínez and Cervantes, 2003; Benavente et al., 2010). Near the YCCV, these faults are several kilometer-long structures extending through the valleys of the Tacalaya and Callazas rivers. These structures affect the Quaternary volcanoes and control their structural development (cf. Samaniego et al., 2015). The secondary NE-SW fault system is represented by local normal faults that control the geothermal surface manifestations, especially those of the Salado and Calientes rivers.

\section{Methodology}

Due to the extremely arid weather conditions of the Central Andes, the volcanic deposits of the YCCV are well preserved. Fieldwork between 2012 and 2014 included geological mapping and sampling of most stratigraphic units, resulting in a broad suite for petrographic, geochemical, and geochronological studies. Major- and trace-element wholerock analyses were obtained at the Laboratoire Géosciences Océan (IUEM-UBO, Brest, France) from agate-crushed powders of 63 samples spanning the entire volcanic history. We used an Inductive Coupled Plasma-Atomic Emission Spectrometer (ICP-AES), following the analytical procedure described by Cotten et al. (1995). Additional information concerning the geochemical data methods is shown in the Supplementary Material 1.

The chronology of the Pleistocene eruptive activity was established using the unspiked K-Ar dating method described in Guillou et al. (2011). Nine samples collected from the main stratigraphic units that encompass the entire history of the volcanic complex were selected for K-Ar dating (Table 1). Additionally, an ignimbrite and three lava samples were dated using the ${ }^{40} \mathrm{Ar} /{ }^{39} \mathrm{Ar}$ technique applied on plagioclases, which are ubiquitous crystals in the samples (Table 2). The corresponding analytical procedures are described in the Supplementary Material 1. ArArCalc software (Koppers, 2002) was used to calculate isochron regressions, weighted mean ages, and probability of fit estimates. Criteria defining isochron ages are described in Sharp and Renne (2005). ${ }^{40} \mathrm{Ar} /{ }^{39} \mathrm{Ar}$ ages are summarized in Table 2 and detailed in Supplementary Material 2. In addition, U-Pb age determinations on zircons were obtained at Laboratoire Magmas et Volcans (Clermont-Ferrand, France) on two samples from the same ignimbrite unit. Previously established analytical techniques (Hurai et al., 2010; Paquette et al., 2014) were adapted to Pleistocene volcanic samples (Paquette et al., 2019). Common Pb 
as well as ${ }^{230} \mathrm{Th} /{ }^{238} \mathrm{U}$ and ${ }^{231} \mathrm{~Pa} /{ }^{235} \mathrm{U}$ disequilibria were corrected according to the methods published by Sakata et al. (2017) and Sakata (2018).

The Late Pleistocene and Holocene chronology of the volcanic activity was constrained by 5 new radiocarbon ages obtained from charcoal samples collected in pyroclastic deposits. These samples were analyzed at the Centre for Isotope Research (CIO), Groningen University (Netherlands). Table 3 gives the conventional ${ }^{14} \mathrm{C}$ ages $( \pm 1 \sigma)$, and the calibrated ages ( $\pm 1 \sigma$ and $2 \sigma$ ). Conversion from conventional ${ }^{14} \mathrm{C}$ ages to calendar ages was carried out using the Calib 7.1 code (Stuiver and Reimer, 1993; Stuiver et al., 2005) and the Southern Hemisphere calibration curve (SHCal13, Hogg et al., 2013), which is applicable up to $50,000 \mathrm{cal} \mathrm{BP}$.

The volcano's morphometric parameters (volcano basal area, height, and volume) were obtained using the methodology of Grosse et al. (2014). Based on a 6-m digital elevation model (obtained from a Spot satellite image processed by INGEMMET’s geomatic service) and the edifice external outline obtained from the geological map (Fig. 2), we computed the substratum topography by applying different interpolation techniques (linear, cubic, inverse distance weighting method). Taking this topographic surface as a reference, we determined the volcano's maximum height and volume.

\section{Morphology and structure}

We propose that the YCCV is composed of two adjacent edifices with contrasting morphologies and eruptive styles (Figs. 2, 3). Calientes volcano (4980 m above sea level, m asl) is at the northern part of the massif, while Yucamane volcano (5495 m asl) is located to the south. Lavas from the lower cone of Yucamane overlap those of the southern flank of Calientes. The YCCV covers an area of $58-60 \mathrm{~km}^{2}$ and has an estimated volume of 20-25 $\mathrm{km}^{3}$. This bulk volume includes moraine deposits, with a volume estimated at $0.5-1 \mathrm{~km}^{3}$ and a conspicuous ignimbrite deposit emplaced at the west and southwest foot of Calientes and south foot of Yucamane with a bulk volume estimated at 8-12 $\mathrm{km}^{3}$ (see below). Both volcanoes are constructed to the south of the highly eroded Yucamane Chico edifice (Figs. 2, 3).

Calientes is a composite cone rising from 4300 to $4980 \mathrm{~m}$ asl with an asymmetric morphology composed of a succession of overlapping lava flows and a truncated summit with a $1 \mathrm{~km}$-wide crater open toward the SE (Figs. 2, 3). A well preserved, $1 \mathrm{~km}$-wide, $500 \mathrm{~m}$-high dome complex fills the mouth of the topographic depression. Although the lower and middle slopes of Calientes display ample evidence of glacial erosion, the summit zone and the dome 
complex lack such evidence, suggesting a post-glacial (Holocene) age. Yucamane is a steepsided, symmetrical composite cone with a roughly circular base (6-8 $\mathrm{km}$ in diameter) and a generally less eroded morphology than Calientes. It rises from 3800 to $5495 \mathrm{~m}$ asl. In the lower part of the cone, lava flows have slopes from $5-15^{\circ}$, while lava flows above $4800 \mathrm{~m}$ asl have steep slopes $\left(>25^{\circ}\right.$ ) (Fig. 3). The volcano is formed by interlayered lava flows and some pyroclastic deposits defining a 1200-m-high cone. Lavas from the middle and lower flanks have been impacted by Pleistocene glaciations and are locally covered by moraine deposits. The edifice's summit is composed of two nested craters of 600 and $350 \mathrm{~m}$ in diameter, the innermost of which is $\sim 120$ m deep. The crater is partially filled by reworked tephra deposits and its inner walls are relatively gently sloping with pervasive fumarolic activity. The eastern foot of the YCCV is a plateau characterized by gentle slopes $\left(<10^{\circ}\right)$ (Figs. 2, 3) and covered by younger tephra-fall deposits.

The morphology of the YCCV was shaped by late Pleistocene glaciations. As a result, moraine deposits are mapped on the western and southern flanks (Fig. 2). These moraines have elongate shapes, heights of tens of meters, and lengths of hundreds of meters. By comparison with other Late Pleistocene Peruvian volcanoes, such as Coropuna (Bromley et al., 2009), Ampato (Samaniego et al., 2015) and Hualca Hualca (Alcalá-Reygosa et al., 2017), we suggest that these moraines were emplaced during the Last Glacial Maximum (LGM) which was roughly dated at 16-25 ka in this part of the Andes (Bromley et al., 2009; Zech et al., 2009). At a regional scale, smaller glacial re-advances such as the Younger Dryas event (10-12 ka; Clapperton, 1993) and other minor Holocene glacial fluctuations (cf. Jomelli et al., 2011) have also been identified, but we found no evidence of such glacial advances at YCCV.

\section{The eruptive chronology of Yucamane-Calientes compound volcano (YCCV)}

The following description of the volcanic units of Calientes and Yucamane edifices (Fig. 2) is based on our morphologic, stratigraphic, and geochronological data.

\subsection{Yucamane Chico lavas}

The older volcanic units of the YCCV rest on top of lavas from Yucamane Chico volcano (6025 m asl), which is located immediately north of the YCCV and is an old and highly eroded edifice displaying a similar degree of erosion as the Barroso Group volcanoes (i.e. Nazaparco). Yucamane Chico is elongated in the WNW-ESE direction, with a steepsided southern flank (Fig. 3). Its lava flows have a porphyritic texture with a mineral assemblage of plagioclase, clinopyroxene, orthopyroxene, Fe-Ti oxides, and minor amphibole 
phenocrysts, embedded within an aphanitic groundmass. An andesitic lava flow from the base of the eastern flank is dated at $5.47 \pm 0.09 \mathrm{Ma}$, whereas another andesitic lava that crops out below the base of the Yucamane cone yielded an age of 6.14 \pm 0.11 Ma (samples YU-12-22 and YU-13-16 respectively, Table 1). These ages are in good agreement with the ages reported for lavas from the neighboring Nazaparco edifice (Martínez and Cervantes, 2003) and confirm a Mio-Pliocene age for Yucamane Chico.

\subsection{Calientes I}

The oldest remnants of the Calientes edifice are sub-horizontal lava flows that crop out on the lower western flank of the volcano (Figs. 2, 3). This succession is composed of 20-60 m-thick, andesitic (60.9-61.9 wt.\% $\mathrm{SiO}_{2}$ ) lava flows resting discordantly on older lavas from the Yucamane Chico edifice and volcanic products from the Plio-Quaternary volcanic formations. A sample collected from a lava flow of this unit has been K-Ar dated at $493 \pm 9$ ka (sample YU-12-50, Table 1).

\subsection{Calientes II: the Callazas Ignimbrite}

Deposits' description. South of Yucamane volcano, conspicuous ignimbrite deposits crop out at the foot of the western and southwestern flanks of Calientes (Figs. 2, 3). These deposits cover the older formations composed of sedimentary and volcanic rocks from Labra and Huaylillas formations, as well as the lavas from the older Calientes I unit. The ignimbrite deposits compose the plateau located between the Callazas and Salado rivers, reaching Laguna Aricota $20 \mathrm{~km}$ to the south of Yucamane's crater (Fig. 2). They are structureless, slightly consolidated, grey to beige in color, and have local maximum thicknesses of 80-100 $\mathrm{m}$. The total reconstructed area of the deposit is $\sim 165 \mathrm{~km}^{2}$ with a minimum volume in the range of 8-12 $\mathrm{km}^{3}$. The deposit's pumices are amphibole-bearing dacites (66-68 wt.\% $\mathrm{SiO}_{2}$ ), representing the most silicic composition of the YCCV.

In the proximal zone (e.g. San Lorenzo, western flank, Fig. 3) at $<6-8 \mathrm{~km}$ from Yucamane summit, the ignimbrite deposit is composed of at least six sub-horizontal pumicerich layers, with individual thicknesses of 6-12 m. The lower part of the succession is well consolidated with incipient welding and deformed pumice fragments. The middle part of the succession consists of lag breccia layers composed of angular to subangular accidental lithic fragments up to $60 \mathrm{~cm}$ in diameter, suggesting proximity to the vent area. The upper part of the succession is $>10 \mathrm{~m}$ of non-consolidated surge deposits with centimetric, planar, and cross-bedded stratification. 
In the medial and distal zones, 6-8 km from the Yucamane volcano, at least three subunits are exposed. The ignimbrite deposits at these zones are structureless, with a total thickness of $40-60 \mathrm{~m}$. The lower level is poorly consolidated, while the middle level is more consolidated, with crude columnar jointing (Fig. 3). The lower and middle layers are grey to whitish-grey, whereas the upper level is yellowish. Pumice as large as $25 \mathrm{~cm}$ in diameter are present $20 \mathrm{~km}$ from the YCCV. In the distal zone, close to Callazas river valley, the ignimbrite deposits are covered by a succession of block-and-ash-flow deposits. We stress that no marked erosion surface has been observed.

Age determination. The Callazas Ignimbrite was dated using the ${ }^{40} \mathrm{Ar} /{ }^{39} \mathrm{Ar}$ method on plagioclases and U-Pb method on zircons. Both methods are described in Supplementary Material 1. The results of ${ }^{40} \mathrm{Ar} /{ }^{39} \mathrm{Ar}$ dating of sample YU-12-78 A are presented as probability diagrams (Deino and Potts, 1990) and inverse isochrones in Fig. 4. A total of 15 populations of 1 to 2 crystals were analyzed. Individual ${ }^{40} \mathrm{Ar} /{ }^{39} \mathrm{Ar}$ ages range between $126.6 \pm 56.3$ and $583.7 \pm 117.6$ ka (Supplementary Material 2). Such scatter may reflect argon loss for the youngest ages and the presence of excess argon and/or antecrysts for the oldest ages. In fact, plagioclase phenocryst in this sample displays two families: the dominant group corresponds to euhedral, non-altered, zoned crystals; whereas the accessory group corresponds to sievecored crystals with frequent dissolution internal zones. Following the definition of Jerram and Martin (2008), we interpret the first group as phenocrysts mostly in equilibrium with the groundmass, and the second group as antecrysts. A reasonable probability of fit (i.e. $\mathrm{p}=0.42$ ) coincides with a roughly Gaussian distribution centered at $198.4 \pm 14.8 \mathrm{ka}$, which is the weighted mean value of the 7 analyses remaining after eliminating the two subzero ages, the youngest age, and the five oldest ages (Fig. 4a). Such a weighted mean age is likely unaffected by excess argon. The corresponding ${ }^{40} \mathrm{Ar} /{ }^{36} \mathrm{Ar}$ initial intercept is $306.0 \pm 8.1$, equivalent to the modern atmospheric ratio. The inverse isochron age (Fig. 4b) calculated using the same population $(170.7 \pm 30.5 \mathrm{ka})$ is also equivalent at the $1 \sigma$ level to the weighted mean of the individual Ar-Ar ages. We apply the alteration index (AI) defined by Baksi (2007), which is a measure of the extent of secondary alteration based on ${ }^{36} \mathrm{Ar}$ and ${ }^{39} \mathrm{Ar}$ contents, to better constrain our data and check that the final age was calculated from unaltered feldspars. Plagioclases are considered unaltered if their AI value is lower than 0.00006. AI values for the two plagioclases yielding subzero age grains are about three to four times higher than the limit, suggesting that they experienced argon loss from alteration. We infer that two additional crystals in the 420-580 ka age range with AI values 2 to 3 times 
higher than the permitted threshold value experienced $\mathrm{K}$ loss during alteration resulting in overestimated ages. Three other grains yielding old ages have AI values lower than the cutoff value. We suggest that these unaltered old grains are xenocrysts. Based on these ${ }^{40} \mathrm{Ar} /{ }^{39} \mathrm{Ar}$ data, we retain the value of $198.4 \pm 14.8 \mathrm{ka}$ (YU-12-78A, Table 2) as the most probable eruption age.

We also obtained U-Pb ages on selected populations of zircon from two samples from the middle subunit (YU-13-07) and the upper surge deposits (YU-12-78A). In both samples, we found similar zircons populations yielding ages corresponding to successive crystallization episodes from $\sim 460$ ka to 160 ka with a period of about 50 ka between each new episode (Supplementary Material 3, Fig. 5). Zircon crystalizes in the magma reservoir prior to eruption and consequently, they provide a maximum estimate for the eruption age. Based on these data, we consider that the eruption age is close to $158 \pm 20 \mathrm{ka}$ and that the older zircons are antecrysts, which were probably related to successive magma input into the reservoir. Both methods yield statistically indistinguishable ages suggesting an eruption age between $158 \pm 20 \mathrm{ka}$ and $197 \pm 16 \mathrm{ka}$ (Fig. 5). These data are in agreement (within errors) with an ${ }^{40} \mathrm{Ar} /{ }^{39} \mathrm{Ar}$ age (YU-12-02, $213.4 \pm 13.5 \mathrm{ka}$, Table 2) obtained on a juvenile sample from a block-and-ash-flow deposit covering the Callazas ignimbrite deposits.

\subsection{Calientes III}

The Calientes III unit predominantly comprises lavas of the middle and upper part of the edifice between 4200 and $5374 \mathrm{~m}$ asl and represents the main cone-building stage of Calientes. The unit consists of a $\sim 1150-1200$ m-thick succession of andesitic and dacitic (60.2-65.1 wt.\% $\mathrm{SiO}_{2}$ ), blocky lava flows. These lavas rest discordantly on remnants of the Calientes I lavas and the Callazas ignimbrite (Figs. 2, 3), and extend as far as $8 \mathrm{~km}$ northwest and $5 \mathrm{~km}$ southwest from the summit. The lavas are strongly affected by glacial erosion, suggesting an age older than the LGM. This observation is confirmed by a K-Ar age of $126 \pm$ 3 ka (YU-12-31, Table 1) and an ${ }^{40} \mathrm{Ar} /{ }^{39} \mathrm{Ar}$ age on plagioclase of $95.6 \pm 16.7 \mathrm{ka}$ (YU-12-44, Table 2) obtained for two different lava flows above the Callazas ignimbrite deposits. As for Callazas ignimbrite, a large amount of the ${ }^{40} \mathrm{Ar} /{ }^{39} \mathrm{Ar}$ dated feldspars are considered antecrysts, only the three youngest and less radiogenic crystals were used to calculate the ${ }^{40} \mathrm{Ar} /{ }^{39} \mathrm{Ar}$ age of this lava flow.

We include in this unit a succession of at least three block-and-ash-flow deposits cropping out on the western side of the Salado river valley, 6-8 km from Yucamane's summit (Figs. 2, 6) and overlying the Callazas ignimbrite deposit. Each layer is 12-18 m-thick, light 
grey, structureless, unconsolidated, and all have gradational contacts between them. The deposits contain 30-40 vol.\% grey juvenile blocks of dacitic composition (63.0-65.9 wt.\% $\mathrm{SiO}_{2}$ ) and 10-15 vol.\% accidental lithic fragments in an ash-rich matrix. A juvenile block from this block-and-ash-flow deposit was dated on plagioclase by ${ }^{40} \mathrm{Ar} /{ }^{39} \mathrm{Ar}$ at $133.4 \pm 13.5 \mathrm{ka}$ (YU-12-68B, Table 2). The ${ }^{40} \mathrm{Ar} /{ }^{39} \mathrm{Ar}$ experiment evidences that even in juvenile blocks older crystals can be trapped. Indeed, only 8 of the 19 dated populations of feldspars are juvenile, the others are xenocrystic,

Lastly, despite not being directly related with this eruptive stage, we include in this unit a young lava dome ( 900 m diameter and $~ 300 \mathrm{~m}$ high) mapped in the upper southern flank of the Mio-Pliocene Yucamane Chico edifice. A lava sample from this dome yielded a K-Ar age of $102 \pm 6$ ka (YU-12-40, Fig. 2; Table 1). The dome’s position and age suggest that different eruptive vents were active during the Calientes III stage.

\subsection{Calientes IV}

The uppermost flank of Calientes and a younger dome complex were constructed during the last eruptive stage of Calientes. The viscous lavas, domes, and coulees of the upper Calientes are cut by a SE-facing, relatively small (1 km-wide) amphitheater probably formed by glacial erosion. The younger dome complex is situated SE of the amphitheater (Figs. 2, 3) and is composed of at least three coalescent lava domes emplaced during a likely long-lasting extrusive event. They extend approximately over a diameter of $1.2 \mathrm{~km}$ and height of $600 \mathrm{~m}$. These domes consist of porphyritic dacites (63-64 wt.\% $\mathrm{SiO}_{2}$ ). The fresh morphology and the lack of glacial erosion of these domes suggest that they were emplaced during the Holocene. A lava sample from the dome complex, which comes from the SW upper flank of Calientes yielded a sub-zero K-Ar age of $3 \pm 3$ ka (YU-14-16, Table 1), supporting a Holocene age.

\subsection{Yucamane I}

The older remnants of Yucamane consist of a 300-m-thick succession of andesitic and dacitic (58.5-64.7 wt.\% $\mathrm{SiO}_{2}$ ), blocky lava flows (Figs. 2, 3) that crop out on the southern flank of the cone and discordantly overly the upper Miocene-Pleistocene products of Yucamane Chico. Samples from Yucamane I stage lavas did not yield meaningful ages because atmospheric contamination was too high to allow detection of ${ }^{40} \mathrm{Ar} *$. Field relationships, nevertheless, support an age younger than the Calientes III stage (i.e. < $100 \mathrm{ka}$ ).

\subsection{Yucamane II}


A thick succession of a directed blast, a debris avalanche, and at least two block-andash-flow deposits overlies the basal lava flows of the Yucamane cone. Such deposits reflect a voluminous dome-forming eruptive stage after the Yucamane sector collapse.

5.7.1. Andesitic directed blast deposit. This unit forms a conspicuous layer that crops out to the west and south of Yucamane volcano, covering a lobe-shaped area of $~ 130-135 \mathrm{~km}^{2}$ (Figs. $6,7)$. Based on the observed maximum thickness of this deposit, we infer a southwestern dispersion axis. The deposit is grey in color, unconsolidated, and its thickness decreases at a relatively constant rate. The deposit is well sorted, fines-depleted, and mainly composed of dense, lapilli-size juvenile blocks (40-50 vol.\%), and accidental lithic fragments (20-30 vol.\%). The juvenile fragments are homogeneous porphyritic andesites (62.3-62.7 wt.\% $\left.\mathrm{SiO}_{2}\right)$.

In the proximal areas, less than $8 \mathrm{~km}$ south and southwest of Yucamane's crater (i.e. Quebrada Honda and Curancurane ravines, Fig. 6), the deposit's thickness ranges between 1 and $5 \mathrm{~m}$, and the juvenile blocks have a maximum diameter of $40 \mathrm{~cm}$. In Quebrada Honda, the deposit overlies an unconsolidated andesitic block-and-ash-flow deposit whereas at Quebrada Curancurane, the deposit overlies the Callazas ignimbrite deposit (Fig. 6). In medial zones, for example near the town of Yucamane, $9 \mathrm{~km}$ south of Yucamane's crater, the deposit overlies the Salado block-and-ash-flow deposits, and underlies the Campanani block-and-ash-flow deposits (see below). No paleosol or erosive contact has been observed at that place. In distal areas more than $12 \mathrm{~km}$ to the west and southwest of Yucamane's summit (i.e. Pampa Coirire, and the town of San Pedro, Fig. 2), the deposit has a thickness between 30 and $80 \mathrm{~cm}$. In such areas, the deposit includes dense porphyritic juvenile blocks with a maximum diameter of 12 $\mathrm{cm}$. The presence of the deposit in such distal sites implies that the pyroclastic density current would have crossed the deep Callazas valley. A ${ }^{14} \mathrm{C}$ date from charcoal collected from the deposit 11 km west from Yucamane’s crater yielded an uncalibrated age of 36,450 \pm 260 BP (sample YU-13-20, Table 3).

We interpret this layer as a lateral blast deposit based on its sedimentological characteristics, abundance of dense juvenile dacitic fragments, lobe-shaped distribution in a narrow sector to the south of YCCV, and progressive thickness decrease without any topographic control. We suggest that the deposit was emplaced by such a dilute pyroclastic density current when a growing lava dome collapsed and subsequently exploded (i.e., Soufrière Hills 1997; Voight et al., 2002; Belousov et al., 2007). 
5.7.2. Debris-avalanche deposit. The deposit crops out between 3 and $14 \mathrm{~km}$ south and southeast from Yucamane's crater, near the town of Santa Cruz and in the Mal Paso and Pampa Pajonal sectors (Fig. 3). In the latter site, the deposit forms hummocky topography. The debris-avalanche deposit is a structureless 40-60 m-thick unit overlying the Callazas ignimbrite. In most locations, the debris-avalanche deposit displays a block-rich facies composed of heterogeneous, dense, sub-angular lava blocks (58-62 wt.\% $\mathrm{SiO}_{2}$ ) that are tens of centimeters to meters in diameter. Some blocks have typical jigsaw-like fractures. Locally, however, the deposit displays a matrix-rich facies containing small fragments of porphyritic lava blocks dispersed in a sandy matrix.

At Quebrada Curancurane, $6 \mathrm{~km}$ west of Yucamane, the debris-avalanche deposit is over $8 \mathrm{~m}$ thick (Fig. 6). The deposit contains dense lava blocks of heterogeneous compositions and up to $3 \mathrm{~m}$ diameter within a matrix composed of sand and gravel. Most blocks have characteristic jigsaw fractures. At this site, the debris-avalanche deposit directly overlies the blast deposit. Such observation, together with the petrographic and geochemical similarities between the debris avalanche blocks and those of the subsequent block-and-ashflow deposits, support a "comagmatic" origin for both deposits and implies that the debrisavalanche deposit originated from the collapse of a voluminous dome complex.

5.7.3. Campanani block-and-ash-flow deposit. The unit crops out in almost all ravines on the south and southwestern flanks of Yucamane (Fig. 7). In the lower part of Quebrada Campanani, near the town of Yucamane Pampa (9 km southwest of Yucamane's crater) and in Quebrada Honda (9 km south of Yucamane's crater), the deposit is 1-8 $\mathrm{m}$ thick, and composed of an ash-rich matrix with angular, andesitic blocks (62-63 wt.\% $\mathrm{SiO}_{2}$ ) that are tens of centimeters to a meter in diameter. The deposit is grey, structureless, slightly consolidated, and overlies the blast deposit (Fig. 7). The contact between the blast and the Campanani deposits is gradational.

5.7.4. Honda block-and-ash flow deposit. In the Quebrada Honda, $9 \mathrm{~km}$ south of Yucamane's crater another block-and-ash-flow deposit crops out, which has an average thickness of 10-12 m (Fig. 6). This reddish grey deposit is structureless and slightly consolidated. It overlies a thin (20-40 cm thick) unconsolidated ash-flow deposit that covers the Campanani block-and-ash-flow deposit. In the middle and upper parts of the sequence, the deposit is slightly reversely graded. The unit's matrix of coarse ash and lapilli composes 6070 vol.\% of the deposit with dense juvenile blocks (up to $1 \mathrm{~m}$ in diameter) forming the 
remaining 30-40 vol.\%. The juvenile blocks are andesitic in composition (61-62 wt.\% $\mathrm{SiO}_{2}$ ). Charcoal from the base of the deposit at a site $8.5 \mathrm{~km}$ west of Yucamane's crater yielded an uncallibrated age of 29,200+170/-160 BP (sample YU-14-11, Table 3). The deposit also crops out in other ravines at the foot of Yucamane's south flank, such as Quebrada Campanani where it is at the top of the pyroclastic succession. The succession is covered by at least six lahar deposits with thicknesses of 10-15 m. Due to the estimated volume of this succession of block-and-ash-flow deposits $\left(0.08-0.11 \mathrm{~km}^{3}\right)$, we infer that a significant domeforming phase followed the Yucamane sector collapse.

\subsection{Yucamane III}

5.8.1. Cone-forming lava flows. These lavas form Yucamane's upper cone between 4300 and $5508 \mathrm{~m}$ asl (Figs. 2, 3). The overlapping lava flows generally have slopes up to 30-40 and maximum run-out distances of 4 to $5 \mathrm{~km}$ from Yucamane's crater. The lavas have basaltic-andesite and andesite compositions (55.2-63.6 wt.\% $\mathrm{SiO}_{2}$ ). A lava sample from the lower western flank was K-Ar dated at $23 \pm 1 \mathrm{ka}$ and a second sample from one of the uppermost lava flows yielded a K-Ar age of $7 \pm 1$ ka (samples YU-12-61 and YU-12-27 respectively, Fig. 2 and Table 1). A third sample collected from a lava flow on the lower southeast flank yielded a K-Ar age of $3 \pm 2$ ka (YU-12-16, Table 1). This latter lava flow is overlain by a younger pumice lapilli tephra fall deposit from Yucamane (see below). Such lava flow activity is in sharp contrast with the volcano's previous dome-collapse activity.

5.8.2. Scoria-flow deposits. The deposits crop out on the lower southwestern and southern flanks of Yucamane (Figs. 8, 9). They have a thickness of $10 \mathrm{~m}$ and are structureless, nonconsolidated, and have a gray-brown, sandy matrix. The deposits have 20-30 vol.\% of blocks and bombs (up to $60 \mathrm{~cm}$ in diameter) and 10-20 vol.\% of dense lithic fragments. Scoria blocks and bombs are basaltic-andesite to andesite in composition (56.7-58.4 wt.\% $\mathrm{SiO}_{2}$ ). At Quebrada Gentilcahua (Fig. 2), the deposits overlie older lava flows of Yucamane's cone as well as the Campanani block-and-ash-flow deposit. To the south, in Quebrada Condorcahua the sequence comprises at least three scoria-flow units with gradational contacts between them that are covered by a 1.5-2.0 m-thick pumice-rich lahar deposit (Figs. 7, 8). This sequence of scoria-flow deposits was emplaced during a period of large explosive eruptions at Yucamane, which probably occurred in the late Pleistocene or early Holocene (see below). 
5.8.3. Scoria-rich tephra-fall deposits. Three scoria-rich tephra-fall deposits crop out on Yucamane's lower south and southeast flanks. Based on the deposits distribution and decrease in thickness, the deposits have a dispersion axis to the southeast (Vela, 2015). These tephrafall deposits overly moraines, which are probably associated with the LGM.

Lower “Halloween” tephra-fall deposit. At Mal Paso hill (4 km from Yucamane’s summit), this deposit is $12-15 \mathrm{~cm}$ thick, whereas it is $8-10 \mathrm{~cm}$ thick in the Hueltajavira sector, which is 6-7 km from the crater (Figs. 8c, 9). The deposit is slightly inversely graded and characterized by a mix of oxidized scoria fragments with an intense orange patina and dark gray, fresh basaltic-andesite (53.9 wt.\% $\mathrm{SiO}_{2}$ ) scoria. Both scoria types compose $60 \mathrm{vol}$ \% of the deposit with the remaining volume composed of dense, grey, aphanitic, and porphyritic andesitic lithic fragments. At $4 \mathrm{~km}$ southeast of the crater, the scoria clasts are less than $4 \mathrm{~cm}$ in diameter, while the lithic fragments are less than $3.5 \mathrm{~cm}$.

“Parda" tephra-fall deposit. At Mal Paso hill, the deposit is 16-18 cm thick (Figs. 8d, 9) and crops out above the Lower Halloween deposit. It also crops out in Quebrada Honda, $9 \mathrm{~km}$ south of the volcano, intercalated into the middle of the sequence of lahar deposits covering the Honda block-and-ash-flow deposits. The Parda deposit is slightly inversely graded at its base and slightly normally graded at the top. The proportion of both scoria and lithic fragments is $\sim 50$ vol.\% each. The andesite (56.6-57.4 wt.\% $\mathrm{SiO}_{2}$ ) scoria fragments are grey with a light-to-medium brown patina and $<3 \mathrm{~cm}$ in diameter at $4 \mathrm{~km}$ from the crater. At the base and top of the deposit, grey, altered lithic lava fragments of sub-centimeter size are predominant.

Upper "Halloween" tephra-fall deposit. In the area around Mal Paso hill, the deposit has a thickness of 12-22 cm (Figs. 8b, 9) and crops out above the Parda and Lower Halloween tephra-fall deposits. The deposit is composed of basaltic-andesitic to andesitic (55.5-56.4 wt.\% $\mathrm{SiO}_{2}$ ), slightly vesiculated scoria (60-70 vol.\%) and dense lithic (30-40 vol.\%) fragments. It is characterized by the presence of altered scoria fragments with a characteristic orange patina, especially in the lower and middle parts of the deposit. At its base, the deposit is slightly inversely graded, while its top is slightly normally graded. At the layer's top, abundant grey, lithic lava fragments of centimeter to millimeter scale are present. At $4 \mathrm{~km}$ from the crater, the maximum size of the scoria measured is $4 \mathrm{~cm}$ and the maximum size of the lithic fragments measured is $3 \mathrm{~cm}$. 
5.8.4. The deposits of the more recent explosive eruptions. On the lower eastern flank of

Yucamane two conspicuous deposits crop out, and are related to Yucamane's more recent explosive activity.

Pumice lapilli fall deposit. On the plateau located between the cone and the Salado river deposit's thickness decreases from $>50 \mathrm{~cm}$ in proximal areas $2-3 \mathrm{~km}$ from the crater to $<5 \mathrm{~cm}$ in medial to distal locations 8-9 km southeast of the crater (Fig. 11). The pumice fragments are yellow grey in color and have an andesitic composition (61.1-62.7 wt.\% $\mathrm{SiO}_{2}$ ). The pumice's maximum diameter decreases from $6.8 \mathrm{~cm}$ in the proximal zone to $2.5 \mathrm{~cm}$ in distal areas. The lithics are composed of fresh (grey) and altered (brown and red) lava fragments that decrease in size from $6 \mathrm{~cm}$ in the proximal zones to $1.5 \mathrm{~cm}$ in distal locations.

In the proximal and medial sectors, this deposit shows three distinct layers. The lower layer is $6 \mathrm{~cm}$ thick in the proximal sector and $<1 \mathrm{~cm}$ thick in the medial sector. It is composed of dark ash dominated by fresh lava fragments. The lithics are $0.5-0.6 \mathrm{~cm}$ in diameter. The lower layer is inversely graded and well sorted. The middle layer is up to $28 \mathrm{~cm}$ thick in the proximal sector and gradually decreases to $6 \mathrm{~cm}$ in distal zones. The pumice lapilli are angular to subangular and highly vesiculated. The layer's lithics are dark grey, non-altered, aphanitic lava fragments. Some hydrothermally-altered lava fragments with a brown to red or yellow color are also present. The layer is inversely graded and well sorted. The upper layer is up to $21 \mathrm{~cm}$ thick in the proximal zone and gradually decreases to $10 \mathrm{~cm}$ thick. Hydrothermally altered lithics are present in a lesser proportion than in the middle layer. The upper layer is structureless and well sorted. The deposit only crops out sporadically in areas $>10 \mathrm{~km}$ from the volcano. A charcoal fragment collected in a fine-grained deposit at the base of the pumice lapilli fall deposit (sample YU-13-15, Table 3) yielded a ${ }^{14} \mathrm{C}$ age of 3,085 \pm 35 BP. Given that no paleosol exists below the tephra-fall deposit, we interpret this layer and the overlying tephra-fall deposit as corresponding to the same eruptive event. We should stress that a quite older ${ }^{14} \mathrm{C}$ age of 3,270 $\pm 50 \mathrm{BP}$ was reported by Rivera and Mariño (2004) from a similar deposit at the base of the pumice lapilli fall deposit.

An isopach map reconstructed from 52 thickness measurements (Fig. 11a) allowed plotting thickness $(\mathrm{T})$ versus the square root of the isopach area $\left(\mathrm{A}^{0.5}\right)$ (Fig. 11b). The resulting diagram reveals a regular thinning that fits a single exponential segment (dashed line 508 in Fig. 11b). Using the Pyle (1989) model, which is based on the exponential decay 
hypothesis, the bulk tephra volume is $0.007 \mathrm{~km}^{3}$. The Fierstein and Nathenson (1992) method yielded similar results. By averaging the diameter of the five largest clasts at each outcrop over the unit's distribution and plotting the lithic isopleths, we estimate the eruption's plume characteristics using Carey and Sparks' (1986) model. Based on this approach, we estimate a column height of 11-12 km above sea level. Given that we are considering neither proximal PDC deposits nor distal fine ash fall deposits, our estimated bulk volume should be considered as a minimum. Based on this assumption, and the estimated column height, this event is classified as a small VEI 3 eruption.

Pyroclastic-flow deposits. At the northeast foot of Yucamane (Pampa Cambaya, $6 \mathrm{~km}$ from the summit), a 5-7 m-thick pyroclastic-flow deposit crops out (Figs. 10,11), which covers an area of $4-5 \mathrm{~km}^{2}$ and has a bulk volume of about $0.009 \mathrm{~km}^{3}$. A similar, though thinner $(<1-2$ m) deposit occurs on the southeast flank of Yucamane. These deposits are composed of three different subunits that overlie the previously described pumice lapilli fall deposit. The lower layer has a red-yellow color and is composed of centimeter size, slightly altered pumice (1520 vol.\%) and lithics (20-25 vol.\%) in a friable, fine ash matrix (50-55 vol.\%). The middle layer is grey and composed of large pumices up to $50 \mathrm{~cm}$ in diameter. The uppermost layer is ash-rich with disseminated pumices up to 20-30 cm in diameter. Pumice bombs with light grey (63.0-64.3 wt.\% $\mathrm{SiO}_{2}$ ) and dark grey (61.5 wt.\% $\mathrm{SiO}_{2}$ ) bands are present in all of these layers.

Charcoal from the base of this pyroclastic-flow deposit yielded a ${ }^{14} \mathrm{C}$ age of 2,990 \pm 35 BP (sample YU-13-06A, Table 3). Comparison between the calibrated ages obtained from this sample and that obtained at the base of the pumice lapilli fall deposit suggests that these deposits probably correspond to two different eruptive events.

\subsubsection{Potential historical activity?}

Historical reports compiled by Siebert et al. (2010) suggest that Yucamane experienced repeated eruptions in 1780, 1787, 1802, 1862, and 1902 CE. Samaniego et al. (2015), however, demonstrate that the 1780-87 and 1802 CE eruptions correspond to the neighboring Tutupaca volcano, which experienced a sector collapse and large explosive event that was radiocarbon dated at $218 \pm 14 \mathrm{BP}$. The historical chronicles of Zamacola (1888) and Valdivia (1847) corroborate that Tutupaca erupted between 1780 and 1802 CE. We found no chronological or historical data supporting a possible eruption at Yucamane in 1862 and 1902 $C E$ and suggest removing these dates from the volcano's eruptive chronology. Currently, 
Yucamane only has low-intensity, but pervasive fumarolic activity in the summit crater. The only other geothermal activity in the region is at Calientes hot springs, located $7.5 \mathrm{~km}$ northeast of Yucamane.

\section{Main petrological characteristics}

\subsection{Petrography}

Calientes lavas are porphyritic andesites ( $\sim 40 \%$ of the dataset) and dacites ( $60 \%)$ with a mineral assemblage of plagioclase, amphibole, biotite, orthopyroxene, clinopyroxene, and magnetite in an intersertal or intergranular groundmass. Plagioclase $(<7 \mathrm{~mm})$ is the most abundant mineral, followed by amphibole $(<2 \mathrm{~mm})$, and pyroxene $(<1 \mathrm{~mm})$. Biotite $(<1 \mathrm{~mm})$ is also present in dacitic samples from Calientes III and IV stages. Phenocrysts compose about 15-20 vol.\% of the rocks. Agglomerates of orthopyroxene, clinopyroxene, plagioclase, and Fe-Ti oxides are also present.

Yucamane lavas are basaltic-andesites ( 10\% of the dataset), andesites ( 30\%), and dacites ( 60\%), with porphyritic textures and intersertal or intergranular groundmasses. Basaltic-andesites are only present in the Yucamane III stage and have a phenocryst assemblage of plagioclase $(<2 \mathrm{~mm})$, clinopyroxene $(<1.5 \mathrm{~mm})$, orthopyroxene $(<600 \mu \mathrm{m})$, amphibole $(<500 \mu \mathrm{m})$, and magnetite $(<200 \mu \mathrm{m})$, with rare olivine $(<300 \mu \mathrm{m})$. Agglomerates of plagioclase, clinopyroxene, amphibole, and magnetite are present in some samples. Andesite and dacite samples have porphyritic textures with an intergranular, intersertal, or glassy groundmass, and have a mineral assemblage of plagioclase $(<2 \mathrm{~mm})$, amphibole $(<3$ $\mathrm{mm})$, biotite $(<3 \mathrm{~mm})$, clinopyroxene $(<600 \mu \mathrm{m})$, and magnetite $(<300 \mu \mathrm{m})$. Olivine $(<300$ $\mu \mathrm{m})$ and orthopyroxene $(<1.0 \mathrm{~mm})$ are present in some andesite samples.

\subsection{Main geochemical characteristics}

Calientes and Yucamane samples define a single high-K magmatic trend, from andesites to dacites (60.1-67.7 wt.\% $\mathrm{SiO}_{2}$ ) for Calientes and from basaltic-andesites to dacites (53.4-66.9 wt.\% $\mathrm{SiO}_{2}$, Table 4) for Yucamane. In general, major oxides (except $\mathrm{Na}_{2} \mathrm{O}$ and $\mathrm{K}_{2} \mathrm{O}$ ) are negatively correlated with silica content. As is common in most arc magma series, the light-ion lithophile elements (LILE, e.g. $\mathrm{K}, \mathrm{Rb}$, Th) and the light rare earth elements (LREE, e.g. La, Ce, Nd) show positive correlations with silica content (Fig. 12), although the LREE have scattered trends. In contrast, Sr, Y, the medium rare earth elements (MREE, e.g. $\mathrm{Sm}, \mathrm{Eu}, \mathrm{Gd}$ ), the heavy rare earth elements (HREE, e.g. Dy, Er, Yb) and the transition metals 
(e.g. $\mathrm{Cr}, \mathrm{Ni}, \mathrm{V}$ ) are all reversely correlated with silica. Some high-field-strength elements (HFSE, e.g. Zr) are also reversely correlated with silica.

The variation diagrams clearly show a single magmatic trend for samples from both Calientes and Yucamane. Slight variations, however, are present in the major and trace elements' behavior through time. For instance, Calientes volcano erupted dominantly andesitic and dacitic magmas with rare eruptions involving silica-rich magmas such as the Callazas ignimbrite (Calientes II stage). In contrast, Yucamane has a different pattern that includes a progressive decrease in silica content through time, with Yucamane's Holocene eruption products being among the most mafic examples from the entire Yucamane-Calientes magmatic series.

\section{Discussion}

\subsection{Evolution of two adjacent edifices}

On the basis of the stratigraphic, geochronological and geochemical data, we propose that Yucamane-Calientes represents a single compound volcano with two, adjacent and partially contemporaneous eruption centers (Fig. 13). Calientes developed from $\sim 500$ ka to the late Holocene ( $\sim 3 \mathrm{ka}$ ) and was characterized by dome-forming activity with a large explosive eruption at $\sim 160-190 \mathrm{ka}$. The large volume (8-12 $\mathrm{km}^{3}$ ) and distribution of the ignimbrite deposits, and the presence of a proximal lag breccia facies in the Río Callazas valley point to a source related with the YCCV. Such an interpretation is consistent with the petrology, which shows that the dacitic pumices of the Callazas ignimbrite form the highsilica end-member of the Yucamane-Calientes magmatic series. Due to the significant volume of these deposits, we suggest this eruption formed a 3-5 km-wide caldera, which is likely concealed beneath Calientes and Yucamane. The bulk volume of the ignimbrite deposits suggests that this eruption is at the limit between VEI 5 and 6. We suggest, however, that because the volume of the potential corresponding tephra-fall deposit is not included that this volume should be considered a minimum. As such, we suggest that this eruption was likely a VEI of 6. As shown in Fig. 13, following the Callazas ignimbrite, the main cone-forming stage of Calientes occurred between 130 and 100 ka (Calientes III stage). After a long timegap, volcanic activity resumed in the Holocene (Calientes IV stage).

Yucamane was constructed on top of the remnants of Calientes' older units (Calientes III stage) and developed since at least 36 ka (i.e. the age of the Yucamane blast deposits). This age is a minimum because we have no age determination for the older Yucamane lava flows (Yucamane I stage). This edifice was very active between $\sim 40$ ka and the Holocene 
610 (Yucamane II and III stages). During at least the late Holocene, both eruptive centers were active. Both edifices, however, produced distinct magmatic products during the Holocene: dominantly dacites for Calientes' recent domes, and basaltic-andesites to andesites for Yucamane, suggesting a complex shallow magmatic plumbing system. Other examples for adjacent and contemporaneously eruptive volcanoes in the Andes include the Mojanda-Fuya Fuya volcanic complex (Robin et al., 2009), which shows contrasting eruptive dynamics and magma chemistry during their Late Pleistocene history. Another example is the twin-peaked Ilinizas volcanoes in the Ecuadorian segment of the Northern Volcanic Zone (Hidalgo et al., 2007). In the Peruvian volcanic arc, the Ampato-Sabancaya compound volcano (Samaniego et al., 2016) also has a progressive shift of the eruptive activity from Ampato to Sabancaya with a transitional period at the Pleistocene-Holocene transition during which both volcanoes were active.

\subsection{Petrogenetic processes at YCCV}

The geochemical study of the major and trace elements shows that the magmatic evolution of the YCCV is controlled by processes that include fractional crystallization and assimilation of crustal materials. This point is clearly shown by the well-defined trends for most major and trace elements as well as the homogeneous spider diagrams for samples from both Yucamane and Calientes edifices (Fig. 14a). To test these hypotheses, a diagram based on the geochemical behavior of one of the most incompatible elements (e.g. Rb) versus a compatible element (e.g. Ni) is commonly used to discriminate fractional crystallization (and other differentiation processes) from source-related partial melting (Janoušek et al., 2015). In a $\log$ (compatible element) versus log (incompatible element) plot, differentiated liquids produced by partial melting show a sub-horizontal trend, whereas fractional crystallization would rise to a sub-vertical trend. Plotting $\log (\mathrm{Ni})$ versus $\log (\mathrm{Rb})$ yields clearly defined subvertical trends (Fig. 14b), suggesting that fractional crystallization is the key process driving magma differentiation at YCCV. Our mineralogical and geochemical data from YucamaneCalientes highlights the prominent role played by fractional crystallization processes as expressed by: (1) the presence of zoned plagioclase and clinopyroxene phenocrysts; (2) the marked correlation between highly incompatible elements; and (3) the depletion of compatible elements along differentiation trends in the magma. For instance, a decrease in Ni and $\mathrm{Cr}$ with increasing silica suggests olivine and/or clinopyroxene fractionation, whereas a decrease in $\mathrm{Sr}$ and Eu concentrations suggests plagioclase crystallization. The depletion in MREE and HREE, which is typical of intermediate and silica-rich Andean magmas further 
strongly suggests a key role of amphibole fractionation in the arc crust (Davidson et al., 2007).

In their regional isotopic study of CVZ magmatism, Mamani et al. (2010) published some isotopic data for Yucamane samples. These data reveal high ${ }^{87} \mathrm{Sr} /{ }^{86} \mathrm{Sr}(0.7064-0.7068)$ and low ${ }^{143} \mathrm{Nd} /{ }^{144} \mathrm{Nd}$ ratios $(0.51226-0.51233)$. They further report $\mathrm{Pb}$ isotope ratios $\left({ }^{206} \mathrm{~Pb} /{ }^{204} \mathrm{~Pb} \quad 18.066-18.220 ;{ }^{207} \mathrm{~Pb} /{ }^{204} \mathrm{~Pb} \quad 15.584-15.643\right.$, and $\left.{ }^{208} \mathrm{~Pb} /{ }^{204} \mathrm{~Pb} \quad 38.474-38.685\right)$ similar to those of the metamorphic basement (Barreiro and Clark, 1984). In general, regional studies highlight the link between $\mathrm{Pb}$ isotope compositions of the upper crust and those of the erupted CVZ magmas (James, 1982; Harmon et al., 1984; Aitcheson et al., 1995). Such Pb isotope data further supports the inference from $\mathrm{Sr}$ and $\mathrm{Nd}$ isotopic systems that CVZ magmas assimilated significant amounts of the regional metamorphic basement during their evolution.

We infer that the Yucamane-Calientes magmas evolved by AFC processes which include significant fractionation of amphibole coupled with assimilation of upper crustal material, following the model for Central Andean magmatism proposed by several authors (e.g., Hildreth and Moorbath, 1988; Davidson et al., 1991; Delacour et al., 2007; Mamani et al., 2010; Godoy et al., 2014; Samaniego et al., 2016; Blum-Oeste and Wörner, 2016; Rivera et al., 2017). The depth of contamination, however, is still debated. Some suggest contamination in the lowermost crust through MASH-type processes (Hildreth and Moorbath, 1988; Davidson et al., 1990; Delacour et al., 2007), whereas others propose that contamination occurred during ascent and storage of the magma through the upper crust (James, 1984; Davidson et al., 1990; Gerbe and Thouret, 2004; Rivera et al., 2017). The models are not mutually exclusive, but a detailed and quantitative assessment of such petrogenetic processes is beyond the scope of this work.

\subsection{Late Holocene eruptive activity and related hazards}

The last eruptive phase of Calientes occurred during the Holocene and was characterized by dome-growth and subsequent collapse. Yucamane also experienced at least 4-5 explosive events during late Holocene times. These eruptions had a local impact and were characterized by tephra-fall deposits that were usually dispersed to the ESE and frequent pyroclastic density currents that swept down the cone, reaching 4-5 km from the summit. Based on geologic and tephrochronologic data, the most probable eruptive scenario at Yucamane would be low-to-moderate magnitude (VEI 1-2) vulcanian activity accompanied by tephra emissions, similar to recent eruptions at Ubinas (2006-2009, 2013-2015 CE) and Sabancaya (1990-1998, 2015-2018 CE). This scenario could evolve to higher magnitude 
events including the emplacement of more voluminous tephra-fall deposits and triggering of pyroclastic density currents around the cone, as occurred during the 3,000 BP, sub-Plinian (VEI 3) eruption of Yucamane. The large magnitude and explosive dome-forming events that impacted the old Yucamane and Calientes edifices were also considered in the volcanic hazard map for the YCCV (Rivera et al., 2018). Secondary lahars may follow any eruptive phases because of rainfall or melting of the snow/ice that usually caps Yucamane's summit during the local winter (December-July).

\section{Conclusions}

The YCCV comprises two successive edifices. Calientes was constructed in four main stages. The older rocks of Calientes are andesitic lava flows at the base of the volcano, dated at 450-500 ka. The Callazas ignimbrite (Calientes II stage) was then emplaced ( 160-190 ka), followed by the main cone-building stage (Calientes III), dated at 130-100 ka. Finally, the Holocene Calientes domes were emplaced and represent the last eruptive products of this edifice. Yucamane was built in three eruptive stages. The Yucamane I stage consists of a sequence of andesitic lava flows exposed at the base of the volcano with an age older than 40 ka. The Yucamane II stage ( 36-30 ka) comprises a thick sequence of block-and-ash-flow deposits that represents a dome-growth episode predating the younger Yucamane cone (Yucamane III stage) dated at 25-3 ka. During the Holocene, Yucamane experienced at least 4-5 explosive eruptions characterized by tephra dispersal and pyroclastic density currents on most flanks of the cone. The last explosive event of Yucamane occurred at 3,000 BP and was a sub-Plinian VEI 3 eruption that emplaced a conspicuous tephra-fall deposit to the eastsoutheast and a pyroclastic-density-current deposit on the northeast and western flanks. Samples from Calientes generally have andesite and dacite compositions (60.1-67.7 wt.\% $\mathrm{SiO}_{2}$ ), while Yucamane's rocks have a slightly larger compositional range from basalticandesites to dacites (53.4-66.9 wt.\% $\mathrm{SiO}_{2}$ ). The rocks have a similar mineral assemblage of plagioclase, amphibole, biotite, ortho- and clino-pyroxene, Fe-Ti oxides, and scarce olivine. Such characteristics suggest that both Calientes and Yucamane belong to a common magmatic system. On the basis of the geologic, geochronological, and petrologic data, we consider Yucamane-Calientes as a potentially active volcanic center.

\section{Acknowledgements}

This work is part of a Peruvian-French cooperation program carried out between the Instituto Geológico, Minero y Metalúrgico (INGEMMET, Peru) and the Institut de Recherche 
pour le Développement (IRD, France). It was partially funded by a "Jeune Equipe Associée à l'IRD” (JEAI) project, which is an initiative designed to promote and strengthen new research teams in developing countries. We warmly thank C. Harpel for comments and language improvements to the previous version of this manuscript. This is Laboratory of Excellence Clervolc contribution $\mathrm{N}^{\circ} \mathrm{XX}$.

\section{References}

Alcalá-Reygosa, J., Palacios, D.,Vázquez-Selem, L., 2017. A preliminary investigation of the timing of the local last glacial maximum and deglaciation on Hualca Hualca volcano Patapampa Altiplano (arid Central Andes, Peru). Quaternary International 449, 149-160.

Aitcheson, S. J., Harmon, R. S., Moorbath, S., Schneider, A., Soler, P., Soria Escalante, E., Steele, G., Swainbank, I., Wörner, G., 1995. Pb isotopes define basement domains of the Altiplano, central Andes. Geology 23, 555-558.

Baksi, A., 2007. A quantitative tool for detecting alteration in undisturbed rocks and minerals - II; application to argon ages related to hotspots. In Geological Society of America Special Paper 430, 305-333.

Barreiro, B.A., Clark, A.H., 1984. Lead isotopic evidence for evolutionary changes in magma-crust interaction, Central Andes, southern Peru. Earth Planet. Sci. Lett. 69, 30-42.

Belousov, A., Voigth, B., Belousov, M., 2007. Directed blasts and blast-generated pyroclastic density currents: a comparison of the Bezymianny 1956, Mount St Helens 1980, and Soufrière Hills, Montserrat 1997 eruptions and deposits. Bull. Volcanol. 69(7), 701-740.

Benavente, C., Carlotto, V., Del Castillo, B., 2010. Extensión en el arco volcánico actual del Sur del Perú. XV Congreso Peruano de Geología. Resúmenes extendidos. Sociedad Geológica del Perú, Pub. Esp. № 9. Cusco p. 766-769.

Blum-Oeste, M., Wörner, G., 2016. Central Andean magmatism can be constrained by three ubiquitous end-members. Terra Nova 28, 434-40.

Bromley, G.R.M., Schaefer, J.M., Wincler, G., Hall, B.L., Todd, C.E., Rademaker, C.K.M., 2009. Relative timing of last glacial maximum and late-glacial events in the central tropical Andes. Quat. Sci. Rev. 28, 2514-2526.

Carey, S., Sparks, R.S.J., 1986. Quantitative models of the fallout and dispersal of tephra from volcanic eruption columns. Bull. Volcanol. 48, 109-125.

Clapperton, C.M., 1993. Quaternary Geology and Geomorphology of South America, Elsevier, Amsterdam, 779 pp. 
Cobeñas, G., Thouret, J.-C., Bonadonna, C., Boivin, P., 2012. The c. 2030 yr BP Plinian eruption of El Misti volcano, Peru: eruption dynamics and hazard implications. J. Volcanol. Geotherm. Res. 241-242, 105-120.

Cotten, J., Le Dez, A., Bau, M., Carroff, M., Maury, R.C., Dulski, P., Fourcade, S., Bohn, M., Brousse, R., 1995. Origin of anomalous rare-earth element and Yttrium enrichments in subaerial exposed basalts: Evidence from French Polynesia. Chem. Geol. 119, 115-138.

Davidson, J.P., McMillan, N.J., Moorbath, S., Wörner, G., Harmon, R.S., López Escobar, L., 1990. The Nevados de Payachata volcanic region $\left(18^{\circ} \mathrm{S} / 69^{\circ} \mathrm{W}, \mathrm{N}\right.$. Chile) II. Evidence for widespread crustal involvement in Andean magmatism. Contrib. Mineral. Petrol. 105, 412-432.

Davidson, J.P., Harmon, R.S., Wörner, G., 1991. The source of the Central Andes magmas; some considerations. In Andean magmatism and its tectonic setting. Geological Society of America-Special Paper 265, 233-243.

Davidson, J., Turner, S., Handley, H., Macpherson, C., Dosseto, A., 2007. Amphibole sponge in arc crust? Geology 35, 787-790.

Deino, A., Potts, R., 1990. Single-crystal 40Ar/39Ar dating of the Olorgesailie Formation, Southern Kenya Rift: Journal of Geophysical Research 95, 8453-8470.

Delacour, A., Gerbe, M.-C., Thouret, J.-C., Wörner, G., Paquereau, P., 2007. Magma evolution of Quaternary minor volcanic centres in southern Peru, Central Andes. Bull. Volcanol. 69, 581-608.

De La Cruz, N., De la Cruz O., 2000. Mapa geológico del cuadrángulo de Tarata, a escala 1/50000, INGEMMET.

De Silva, S.L., Francis, P.W., 1991. Volcanoes of the Central Andes. Springer-Verlag Berlin Heidelberg, Germany, 219 p.

Fierstein, J., Nathenson, M., 1992. Another look at the calculation of fallout tephra volumes. Bull. Volcanol. 54, 156-167.

Gerbe, M.-C., Thouret, J.-C., 2004. Role of magma mixing in the petrogenesis of lavas erupted through the 1990-98 explosive activity of Nevado Sabancaya in south Peru. Bull. Volcanol. 66, 541-561.

Godoy, B., Wörner, G., Kojima, S., Aguilera, F., Simnon, K., 2014. Low-pressure evolution of arc magmas in thickened crust: The San Pedro-Linzor volcanic chain, Central Andes, Northern Chile. J. South Am. Earth Sci. 52, 24-42. 
Grosse, P., Euillades, P.A., Euillades, L.D., van Wyk de Vries, B., 2014. A global database of composite volcanomorphometry. Bull. Volcanol. 76, 784.

Guillou, H., Nomade, S., Carracedo, J.C., Kissel, C., Laj, C., Perez Torrado, F.J., Wandres, C., 2011. Effectiveness of combined unspiked $\mathrm{K}-\mathrm{Ar}$ and $40 \mathrm{Ar} / 39 \mathrm{Ar}$ dating methods in the $14 \mathrm{C}$ age range. Quaternary Geochronology, 6, 530-538.

Harmon, R.S., Barreiro, B.A., Moorbath, S., Hoefs, J., Francis, P.W., Thorpe, R.S, Déruelle, B., McHugh, J., Viglino, J.A., 1984. Regional O-, Sr-, and Pb-isotope relationships in late Cenozoic calc-alkaline lavas of the Andean Cordillera. J. Geol. Soc. London 141, 5, 803-822.

Harpel, C., de Silva, S., Salas, G., 2011. The 2 ka eruption of Misti volcano, southern PeruThe most recent Plinian eruption of Arequipa's iconic volcano. Geol. Soc. Am. Spec. Pap. 484, 72 pp.

Hidalgo, S., Monzier, M., Martin, H., Chazot, G., Eissen, J.P., Cotten, J., 2007. Adakitic magmas in the Ecuadorian Volcanic Front: Petrogenesis of the Iliniza Volcanic Complex (Ecuador). Journal of Volcanology and Geothermal Research 159, 366-392.

Hildreth, W., Moorbath, S., 1988. Crustal contributions to arc magmatism in the Andes of Central Chile. Contrib. Mineral. Petrol. 98, 455-489.

Hogg, A.G., Hua, Q., Blackwell, P.G., Niu, M., Buck, C.E., Guilderson, T.P., Heaton, T.J., Palmer, J.G., Reimer, P.J., Reimer, R.W., Turney, C.S.M., Zimmerman, S.R.H., 2013. SHcal13 southern hemisphere calibration, 0-50,000 years cal BP. Radiocarbon 55, 1889-1903.

Hurai, V., Paquette, J.-L., Huraiová, M., Konečný, P., 2010. U-Th-Pb geochronology of zircon and monazite from syenite and pincinite xenoliths in Pliocene alkali basalts of the intra-Carpathian back-arc basin. J. Volcanol. Geotherm. Res. 198, 275-287.

INEI, 2018. Resultados definitivos de los censos nacionales 2017 Tacna: XII de Población y VII de vivienda y III de comunidades indígenas. Tomo I. Lima. 929 pp.

James, D.E., 1982. A combined O, Sr, Nd, and Pb isotopic and trace element study of crustal contamination in central Andean lavas, I. Local geochemical variations. Earth. Planet. Sci. Lett. 57, 47-62.

James, D.E., 1984. Quantitative models for crustal contamination in the central and northern Andes. In Harmon, R.S., Barreiro, B.A., (eds), Andean Magmatism. Chemical and isotopic constraints. Shiva Publishing Limited, 124-138.

Janoušek, V., Moyen, J-F., Martin, H., Erban, V., Farrow, C., 2015. Geochemical modelling of igneous processes: Principles and recipes in $\mathrm{R}$ language. Bringing the power of $\mathrm{R}$ to a 
geochemical community. Springer Geochemistry; Springer-Verlag Berlin and Heidelberg, 345 p.

Jerram, D.A., Martin, V.M., 2008. Understanding crystal populations and their significance through the magma plumbing system. In Annen, C., Zellmer, G.F. (eds), Dynamics of Crustal Magma Transfer, Storage and Differentiation. Geological Society, London, Special Publications 304, 133-148.

Jomelli, V., Khodri, M., Favier, V., Brunstein, D., Ledru, M.P., Wagnon, P., Blard, P.H., Sicart, J.E., Braucher, R., Grancher, D., Bourlès, D.L., Braconnot, P., Vuille, M., 2011. Irregular tropical glacier retreat over the Holocene epoch driven by progressive warming. Nature 474, 196-199.

Koppers, A.A.P., 2002. ArArCALC - software for Ar-40/Ar-39 age calculations. Computers and Geosciences 28, 605-619.

Mamani, M., Wörner, G., Sempere, T., 2010. Geochemical variations in igneous rocks of the Central Andean orocline ( $13{ }^{\circ} \mathrm{S}$ to $\left.18{ }^{\circ} \mathrm{S}\right)$ : Tracing crustal thickening and magma generation through time and space. Geol. Soc. Am. Bull. 122, 162-182.

Martínez, W., Cervantes, J., 2003. Rocas igneas en el sur del Perú: nuevos datos geocronométricos, geoquímicos y estructurales entre los paralelos $16^{\circ}$ y $18^{\circ} 30^{\prime}$ Latitud sur. Boletín INGEMMET 26, Serie D, Estudios Regionales 140 p.

Paquette, J.-L., Piro, J.-L., Devidal, J.-L., Bosse, V., Didier, A., Sannac, S., Abdelnour, Y., 2014. Sensitivity Enhancement in LA-ICP-MS by $\mathrm{N}_{2}$ Addition to Carrier Gas: Application to Radiometric Dating of U-Th-Bearing Minerals. Agilent ICP-MS J., 58, $4-5$.

Paquette, J.L., Médard, E., Francomme, J., Bachèlery, P., Hénot, J.M., 2019. LA-ICP-MS $\mathrm{U} / \mathrm{Pb}$ zircon timescale constraints of the Pleistocene latest magmatic activity in the Sancy stratovolcano (French Massif Central). J. Volcanol. Geotherm. Res. 374, 52-61.

Peccerillo, P., Taylor, S.R., 1976. Geochemistry of Eocene calc-alkaline volcanic rocks from the Kastamonu area. Northern Turkey. Contrib. Mineral. Petrol. 58, 63-81.

Pyle, D.M., 1989. The thickness, volume and grainsize of tephra fall deposits. Bull. Volcanol. 51, 1-15.

Quang, C.X., Clark, A.H., Lee, J.K.W., 2005. Response of supergene processes to episodic Cenozoic uplift, pediment erosion, and ignimbrite eruption in the Porphyry Copper Province of southern Peru. Econ. Geol. 100, 87-114.

Rivera, M., Mariño, J., 2004. Volcán Yucamane (sur del Perú): geología, petrología y evaluación preliminar de las amenazas volcánicas. Bol. Soc. Geol. Perú 98, 7-27. 
Rivera, M., Martin, H., Le Pennec J.L., Thouret, J.C., Gourgaud, A., Gerbe, M.Ch. 2017. Petro-geochemical constraints on the source and evolution of magmas at El Misti volcano (Peru). Lithos Vol 268-271, 240-259.

Rivera, M., Samaniego, P., Vela J., Le Pennec J.L. 2018. Geología y Evaluación de Peligros del Complejo Volcánico Yucamane-Calientes. Boletín Serie C: Geodinámica e Ingeniería Nº5, INGEMMET, 117 pp.

Robin, C., Eissen, J.P., Samaniego, P., Martin, H., Hall, M., Cotten, J., 2009. Evolution of the late Pleistocene Mojanda-Fuya Fuya volcanic complex (Ecuador), by progressive adakitic involvement in mantle magma sources. Bull. Volcanol. 71, 233-258.

Sakata, S., 2018. A practical method for calculating the U-Pb age of Quaternary zircon: Corrections for common $\mathrm{Pb}$ and initial disequilibria. Geochem. J. 52, 1-6.

Sakata, S., Hirakawa, S., Iwano, H., Danhara, T., Guillong, M., Hirata, T., 2017. A new approach for constraining the magnitude of initial disequilibrium in Quaternary zircons by coupled uranium and thorium decay series dating. Quat. Geochronol. 37, 1-12.

Samaniego, P., Valderrama, P., Mariño J., Van Wyk de Vries, B., Roche, O., Manrique, N., Chedeville C., Liorzou, C., Fidel L., Malnati, J., 2015. The historical (218 \pm 14 aBP) explosive eruption of Tutupaca volcano (Southern Peru). Bull. Volcanol. 77, 51-69.

Samaniego, P., Rivera, M., Mariño, J., Guillou, H., Liorzou, C., Zerathe, S., Delgado, R., Valderrama, P., 2016. The eruptive chronology of the Ampato-Sabancaya volcanic complex (Southern Peru). J. Volcanol. Geotherm. Res. 323, 110-128.

Sébrier, M., Soler, P., 1991. Tectonics and magmatism in the Peruvian Andes from late Oligocene time to the Present, Geol. Soc. America, Spec. Paper 265, 259-277.

Siebert, L., Simkim, T., Kimberley, P., 2010. Volcanoes of the World. 3. ed. Washington, D.C.: Smithsonian Institution, Beckerel, CA: University of California Press, 551 p.

Sharp, W.D. Renne, P.R., 2005. The 40Ar/39Ar dating of core recovered by the Hawaii Scientific Drilling Project (phase 2), Hilo, Hawaii. Geochemistry, Geophysics, Geosystems 6, Q04G17, doi:10.1029/2004GC000846.

Stern, C.R., 2004. Active Andean volcanism: its geologic and tectonic setting. Revista Geológica de Chile 31, 161-206.

Stuiver, M., Reimer, P.J., 1993. Extended 14C database and revised CALIB radiocarbon calibration program. Radiocarbon 35, 215-230.

Stuiver, M., Reimer, P.J., Reimer, R.W., 2005. CALIB 5.0. [WWW Program and Documentation]. 
Sun, S., McDonough, W.F., 1989. Chemical and isotopic systematics of oceanic basalts: Implications for mantle composition and processes. Magmatism in the Ocean Basin, Geol. Soc. Am. Bull. Spec. Pap. 42, 313-345.

Thouret, J.C., Finizola, A., Fornari, M., Suni, J., Legeley-Padovani, A., Frechen, M., 2001. Geology of El Misti volcano nearby the city of Arequipa, Peru. Geol. Soc. Am. Bull. 113, 1593-1610.

Thouret, J.C., Juvigné, E., Gourgaud, A., Boivin P., Davila C., 2002. Reconstruction of the AD 1600 Huaynaputina eruption based on the correlation of geologic evidence with early Spanish chronicles. J. Volcanol. Geotherm. Res. 115, 529-570.

Thouret, J.C., Rivera, M., Wörner, G., Gerbe, M., Finizola, A., Fornari, M., Gonzales, K., 2005. Ubinas: the evolution of the historically most active volcano in southern Peru. Bull. Volcanol. 67, 557-589.

Thouret, J.C., Jicha, B., Paquette J.-L., Cubukcu, E., 2016. A 25 myr chronostratigraphy of ignimbrites in south Peru: implications for the volcanic history of the Central Andes. J. Geol. Soc. London 173, 734-756.

Tosdal, R.M., Farrar, E., Clark, A.H., 1981. K-Ar Geocronology of the late Cenozoic Volcanic Rocks of the Cordillera Occidental. Southern Perú. J. Volcanol. Geotherm. Res. 10, 157-173.

Valdivia, D., 1847. Historia de Arequipa. Folletin El Deber, Arequipa, p. 109-111.

Vela, J., 2015. Estudio tefroestratigráfico de los depósitos asociados con las erupciones recientes del volcán Yucamane (Tacna). Tesis de Ing. Geólogo, Universidad Nacional de San Agustín de Arequipa, 114 p.

Voight, B., Komorowski, J. C., Norton, G. E., Belousov, A., Belousova, M., Boudon, G., Francis, P. W., Franz, W., Heinrich, P., Sparks, R. S. J., Young, S. R., 2002. In Druitt, T.H., Kokelaar, B. (eds) The Eruption of Soufrière Hills Volcano, Montserrat, from 1995 to 1999, The 26 December (Boxing Day) 1997 sector collapse and debris avalanche at Soufrière Hills volcano, Montserrat. Geol. Soc. London Mem. 21, 363-407.

Zamacola, J., 1888. Apuntes para la historia de Arequipa. Año de 1804. Arequipa: Imp. de La Bolsa, 98 p.

Zech, R., Smith J., Kaplan, M.R., 2009. Chronologies of the Last Glacial Maximum and its termination in the Andes $\left(\sim 10-55^{\circ} \mathrm{S}\right)$ based on surface exposure dating. En: Vimeux, F., Sylvestre, F., Khodri, M. (eds). Past climate variability in South America and 
sourrounding regions: from the Last Glacial Maximum to the Holocene. Berlin: Springer, Developments in Paleoenvironmental Research 14, 61-87.

Figures

Fig. 1. (a) Location map of South American volcanic zones: Northern (NVZ), Central (CVZ), Southern (SVZ), and Austral (AVZ) (modified after Stern, 2004). (b) Northernmost part of the CVZ in southern Peru (modified after Thouret et al., 2005). The YCCV is located south of the Plio-Quaternary volcanic range of southern Peru, $13 \mathrm{~km}$ northeast of the town of Candarave. (c) View of the western flank of Yucamane and Calientes from Candarave.

Fig. 2. Geologic map of YCCV showing the locations of dated rock samples.

Fig. 3. Panoramic view of YCCV showing some of the main structures. (a) View from the west showing the former Calientes and Yucamane stratocones near Yucamane Chico. (b) A recent dome complex between Calientes and Yucamane that was not affected by PleistoceneHolocene glacial activity. (c) Callazas ignimbrite emplaced at ca. 160-190 ka, exposed above the San Lorenzo sector, 8 km west of Calientes' summit.

Fig. 4. (a) Density plot (red continuous curve) of anorthoclase crystals from sample YU-1278, along with individual ${ }^{40} \mathrm{Ar} /{ }^{39} \mathrm{Ar}$ age distribution (error bars are $2 \sigma$ ). The grey curve is plotted using all analyses. The red curve uses analyses providing the best probability of fit (red dots in the age distribution diagrams). $\mathrm{N}=$ number of crystals retained in the age calculation over the number of crystals analyzed. P = probability of fit. (b) Inverse isochrones depicting ${ }^{40} \mathrm{Ar} /{ }^{39} \mathrm{Ar}$ results. Uncertainties are $\pm 1 \sigma$. Grey ellipses are not included in the inverse isochron calculations.

Fig. 5. Plot of LA-ICP-MS ${ }^{231} \mathrm{~Pa}-{ }^{230} \mathrm{Th}$ corrected U-Pb zircon ages according to rank. Vertical black bars represent $2 \sigma$ analytical uncertainties. The grey horizontal bands are cumulative weighted mean values for the considered population. Both samples come from the Callazas ignimbrite: (a) Sample YU-12-78A represents the upper surge deposits and (b) YU-13-07 is from the structureless middle unit. 
Fig. 6. (a) Sequence of blast, debris-avalanche, and block-and-ash-flow deposits exposed on the north-western bank of Quebrada Curancurane, $6 \mathrm{~km}$ southwest of Yucamane. (b) Sequence of Salado dacitic block-and-ash-flow deposits exposed on the western bank of Río Salado, 7 km southeast of Yucamane. (c) Pyroclastic succession in Quebrada Honda, 9 km south of Yucamane.

Fig. 7. Stratigraphic sections of pyroclastic-flow and tephra-fall deposits associated with 950 YCCV. UTM Easting and Northing are given below the section name.

Fig. 8. (a) Scoria-rich pyroclastic-flow deposit cropping out on the western bank of Quebrada Condorcahua ravine, $7 \mathrm{~km}$ southwest of the crater of Yucamane, covered by a pumice-rich lahar deposit. (b) Lower Halloween and Upper Halloween scoria-rich tephra-fall deposits that crop out in the Hueltajavira sector, $6 \mathrm{~km}$ southeast of Yucamane's crater. (c) Lower Halloween tephra-fall deposit in the Mal Paso area, $4 \mathrm{~km}$ south of the crater. (d) Parda scoriarich tephra-fall deposit cropping out $4.5 \mathrm{~km}$ south of the crater.

Fig. 9. Stratigraphic sections of the pyroclastic-flow and tephra-fall deposits associated with YCCV. UTM Easting and Northing are included below the section's name.

Fig. 11. (a) Map showing isopachs for the pumice lapilli-rich tephra-fall deposit dated at 3,085 \pm 35 BP and area covered by associated ash-and-pumice-rich pyroclastic flows. (b) T vs. $\mathrm{A}^{0.5}$ diagram, $\mathrm{T}$ and $\mathrm{A}$ being thickness and surface covered by isopachs respectively.

Fig. 12. Selected major and trace elements for Yucamane-Calientes samples, plotted against silica. (a) $\mathrm{SiO}_{2}$ vs. $\mathrm{K}_{2} \mathrm{O}$ classification diagram. A andesites, D dacites, $\mathrm{R}$ rhyolites, $\mathrm{MK}$ medium potassium, HK high-potassium (after Peccerillo and Taylor, 1976). (b-h) Variation diagrams for $\mathrm{Al}_{2} \mathrm{O}_{3}, \mathrm{MgO}, \mathrm{Sr}, \mathrm{Zr}, \mathrm{Rb}, \mathrm{K}_{2} \mathrm{O} / \mathrm{TiO}_{2}$, and La, respectively.

Fig. 13. Composite lithostratigraphic section showing the geologic and volcanologic evolution of YCCV. 
Fig. 14. (a) Multi-element diagrams normalized to primitive mantle (Sun and McDonough, 979 1989) showing typical trace element patterns of continental arc magmas in YucamaneCalientes samples. (b) Log (Ni) vs. Log (Rb) diagram for Yucamane-Calientes samples. We

Table 1. K-Ar ages for rocks from the Yucamane-Calientes compound volcano.

Table 2. ${ }^{40} \mathrm{Ar} /{ }^{39} \mathrm{Ar}$ ages for rocks from the Yucamane-Calientes compound volcano. The ages considered in the text are the weighted mean ages (in bold).

Table 3. ${ }^{14} \mathrm{C}$ data for YCCV measured at the Center for Isotope Research, Groningen University (The Netherlands).

Table 4. Selected geochemical analyses representative of the main volcanic units of YCCV.

Supplementary material 1. Analytical methods.

Supplementary material 2. ${ }^{40} \mathrm{Ar} /{ }^{39} \mathrm{Ar}$ data from laser-fusion experiments on plagioclase crystals relative to 1.1891 Ma ACs-2 flux standard.

Supplementary material 3. In situ U-Pb zircon data measured by LA-ICP-MS on YU-12$100178 \mathrm{~A}$ and YU-13-07 samples. 


\section{Highlights}

-Yucamane-Calientes is a compound volcano composed of two edifices of middle Pleistocene to the Holocene

- Calientes has been constructed in four stages since 500 ka and Holocene

- Yucamane has been constructed in three stages between 40 ka and Holocene

- Samples from both volcanoes are high-K calc-alkaline andesites and dacites

-During the Holocene, Yucamane experienced repetitive vulcanian to sub-plinian eruptive aactivity that emplaced tephra-fall and pyroclastic-density-current deposits

- Yucamane-Calientes should be considered as a potentially threatening volcano 

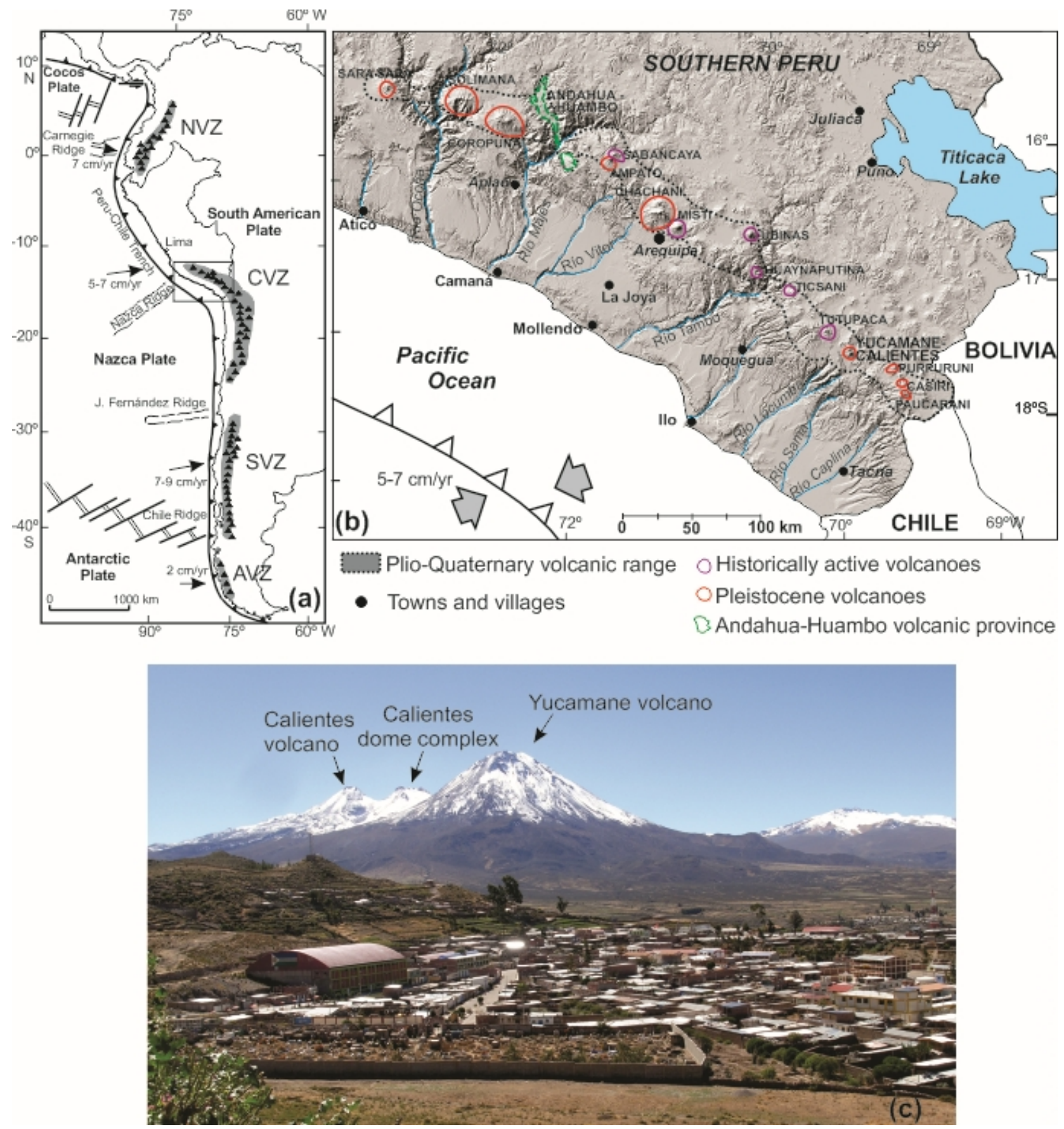


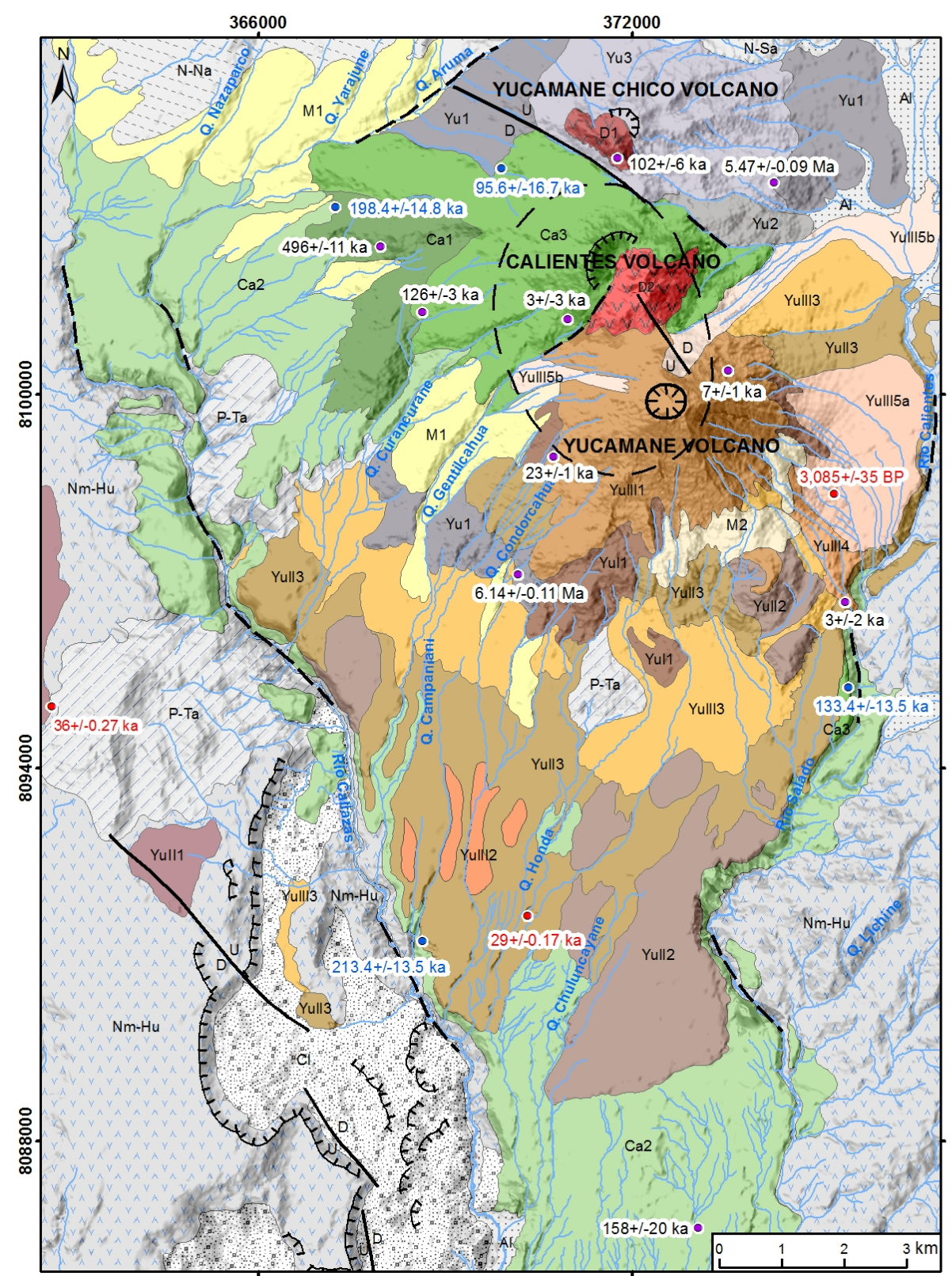

YUCAMANE CHICO AND 䍃

Colluvial deposit

点

山峈占 M2 Younger moraines

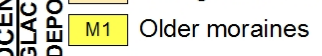

오

는

Andesitic dome of Yucamane Chico Apper-cone of Yucamane Chico

flows of the

Yu2 intermediate-cone of

Yucamane Chico

Yu1 Andesitic lava flows of the

Chico

N-Sa San Pedro lava flows

N-Nà- Nazaparco lava flows

Nm-Hu Huaylillas Ignimbrite

P-Tá Tacaza lava flows
Andesitic lava flows of the

lower-cone of Yucamane

CALIENTES

YUCAMANE
Dacitic domes of Calientes
Yulli5b Pumice-flow deposit

Yulli5a Tephra-fall deposit

Yulll4 Andesic lava flow

Yulll3 Volcanoclastic deposit

Yulll2 Scoria-flow deposit

Yull1 Lava flows of the upper cone sequence intercalated with lahars

Yull2 Debris-avalanche deposit

Yull1 Blast deposit

Yul1 Lava flows of the lower cone

Andesitic and dacitic lava flows and block-and-ash flow deposits

Ca2 Callazas Ignimbrite

Andesitic lava flows at the base-cone
Pyroclastic density current

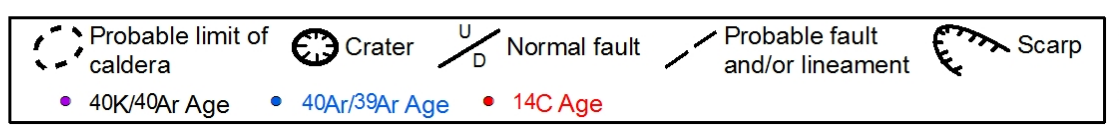




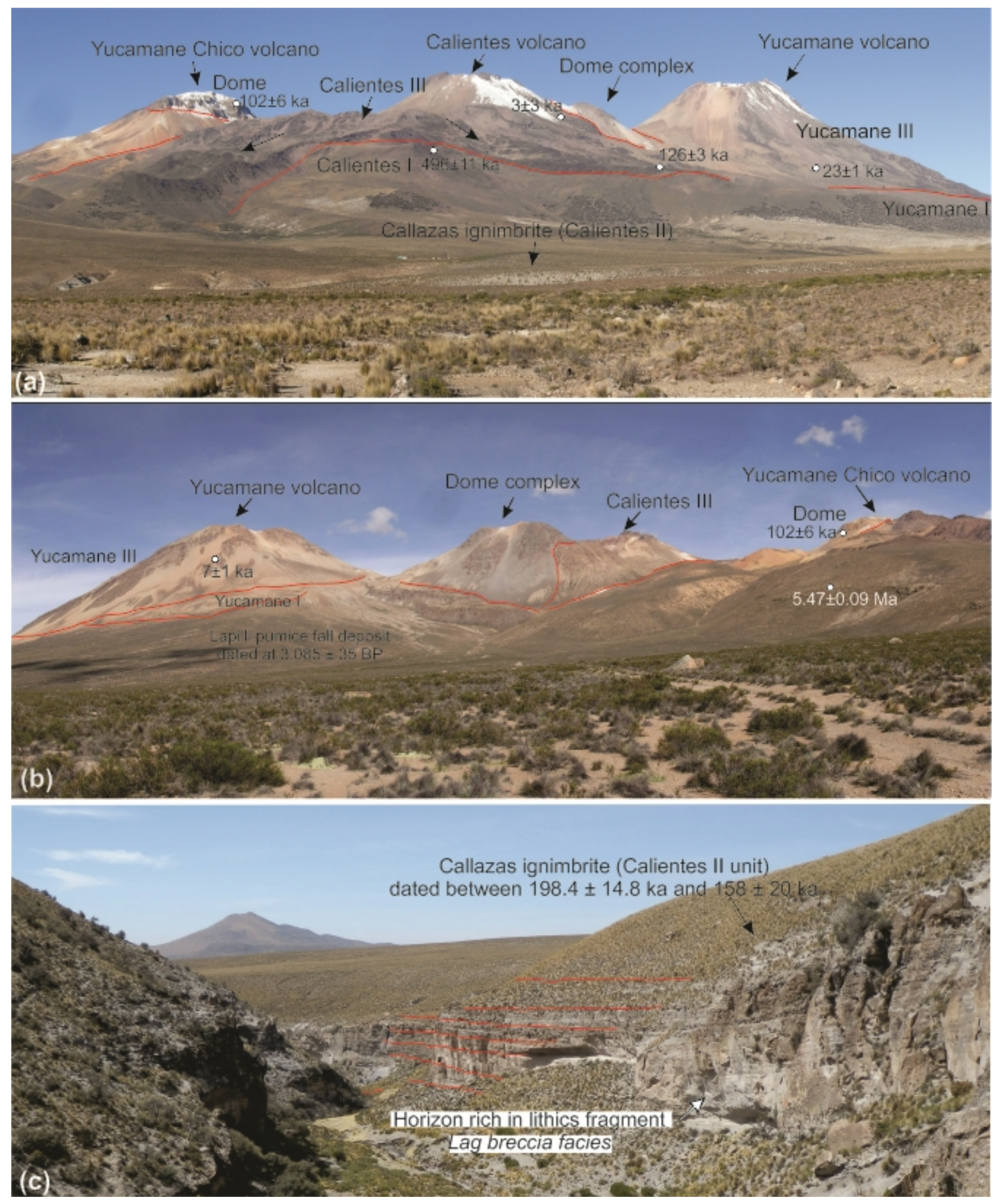



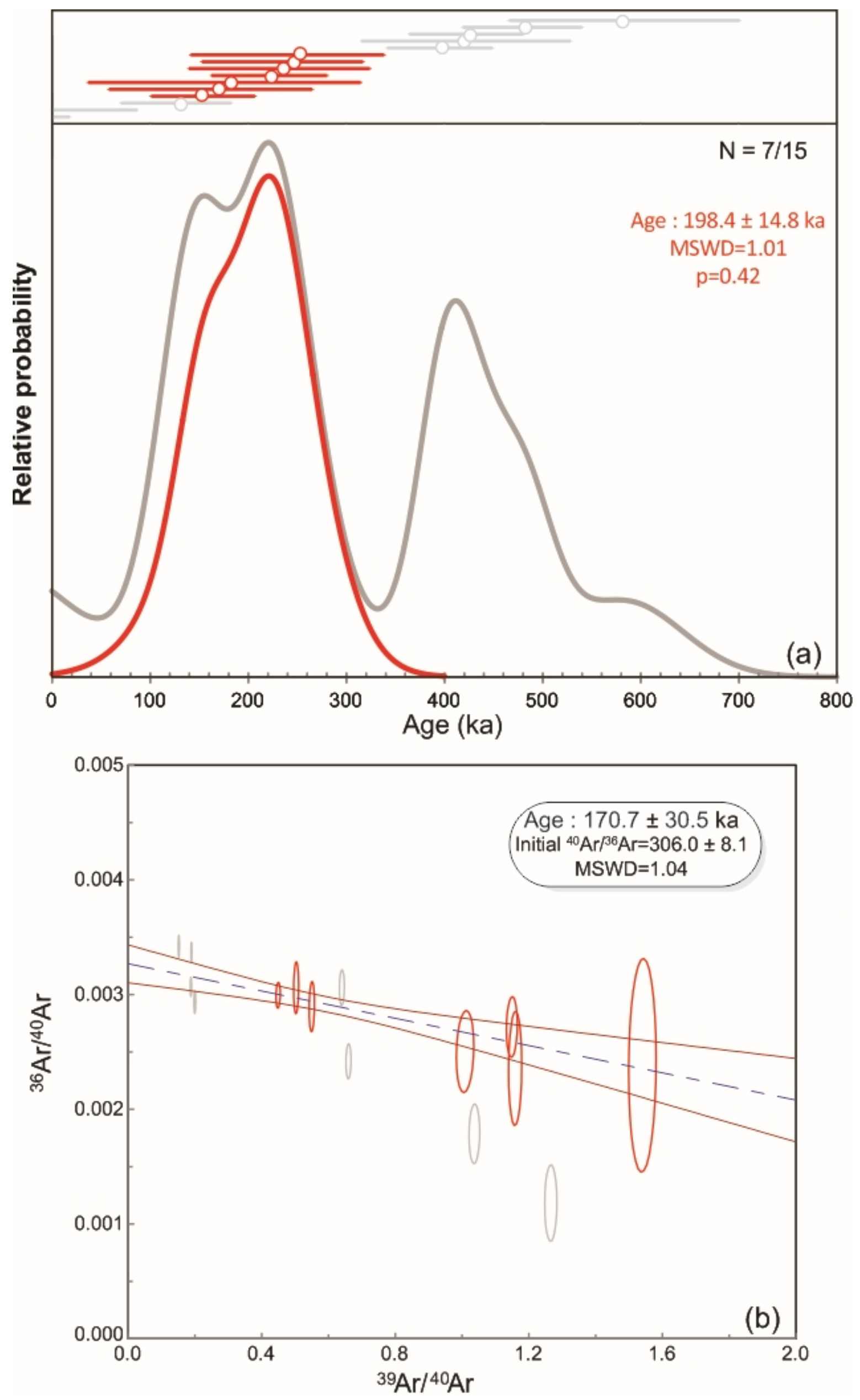

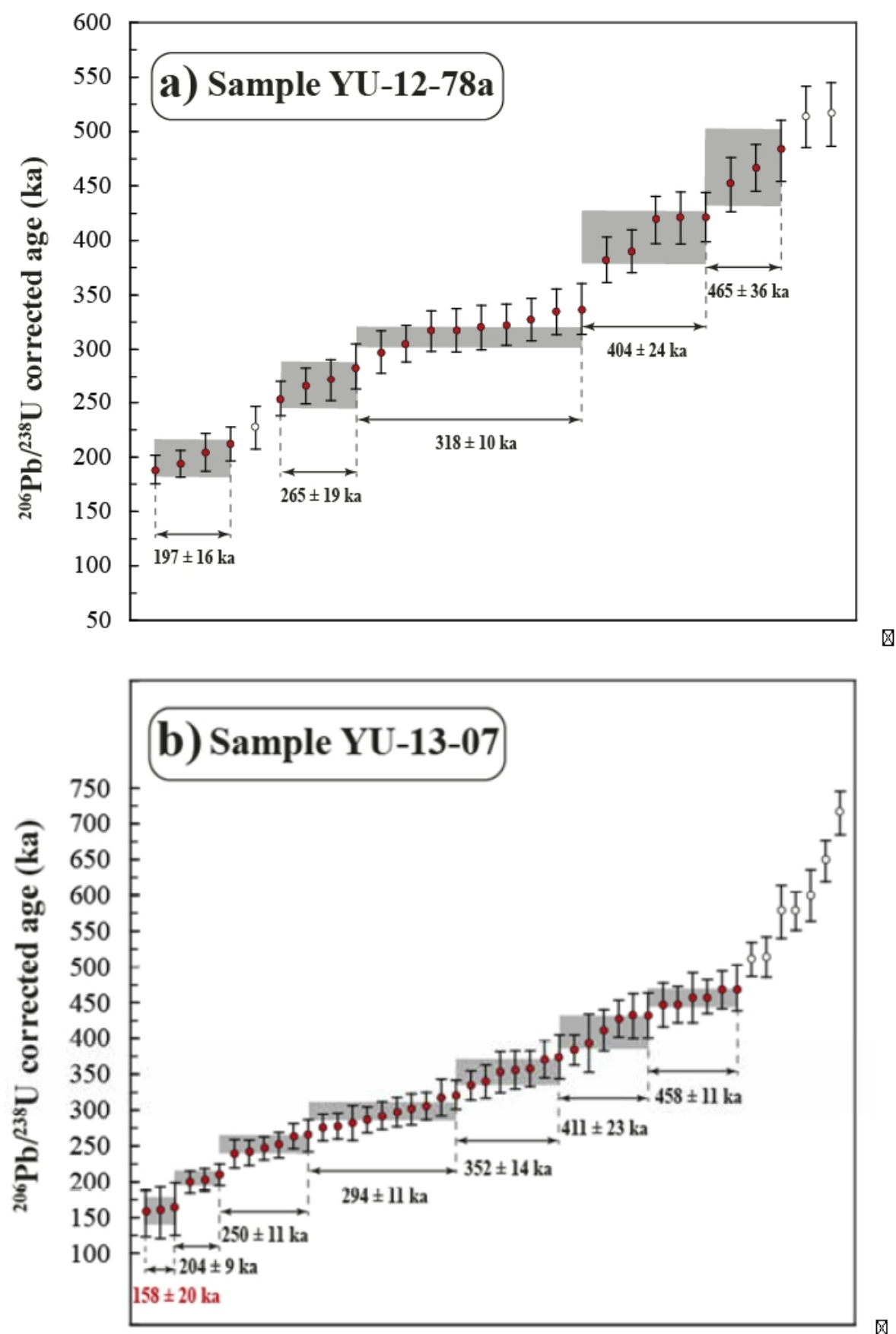


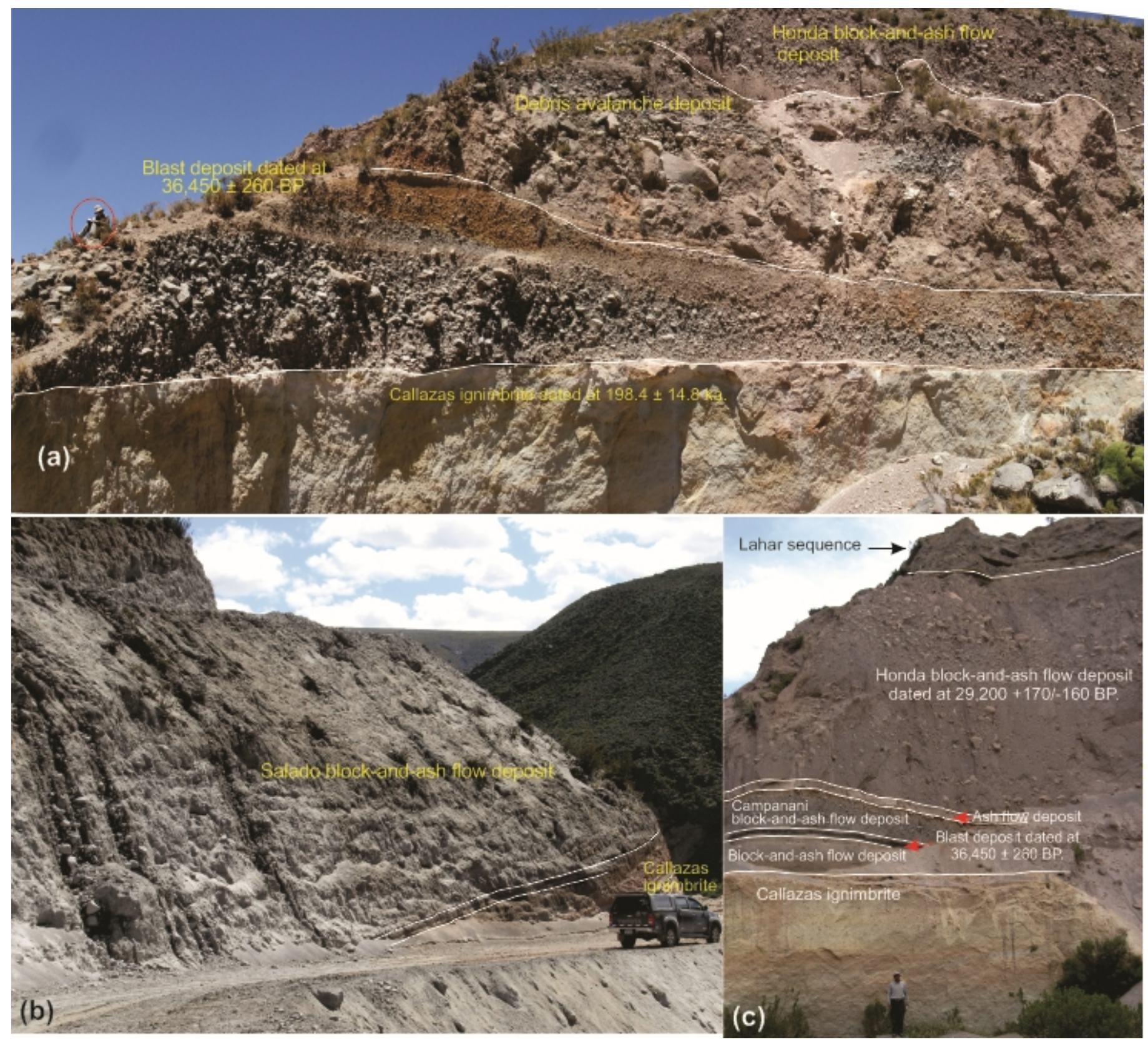


$x$

Yucamane town

368814 E-8091579 N Quebrada Campanani

Quebrada Honda

$3 \times$

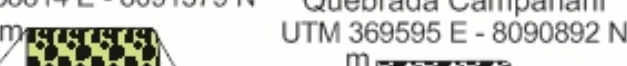

sos. ${ }_{1.4}^{\mathrm{m}} \mathrm{kg}$

Hon 33 .

i.j.:

$1.5 \%$

\%

0

,

$\cos 6$

UTM 370558 E - $8092086 \mathrm{~N}$

$36 \%$

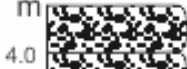

$8 \%$

$0, \pi$

$0 \%$

8

0

$2.0 \%$

tos

35

36

$3 \%$

3.

36

30

35

$4 \times$

30

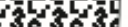

40

0

$0 \%$

96

60

in; $;$

(x)

40 \%

4.4:

,

\%

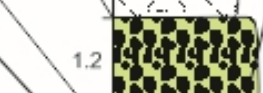

x 35

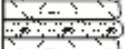

(a)

0.181.

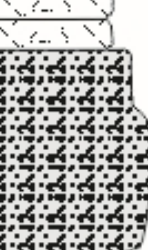

250 \%

in:

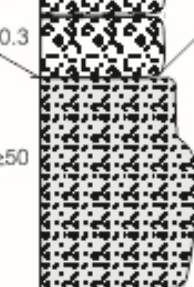

$$
\text { (n) }
$$




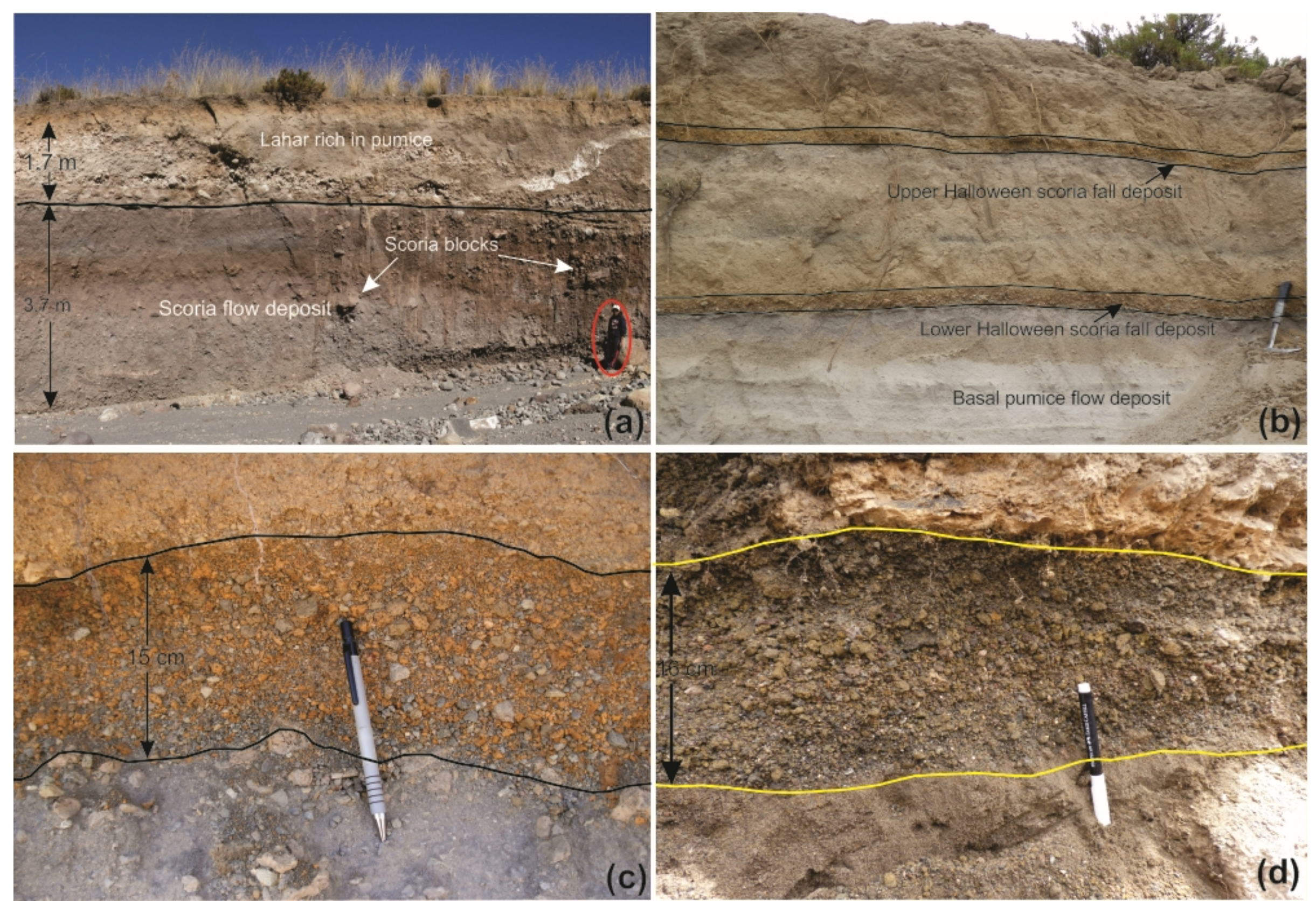


Mal Paso 2 Sector UTM 374106 E - 8096152 N
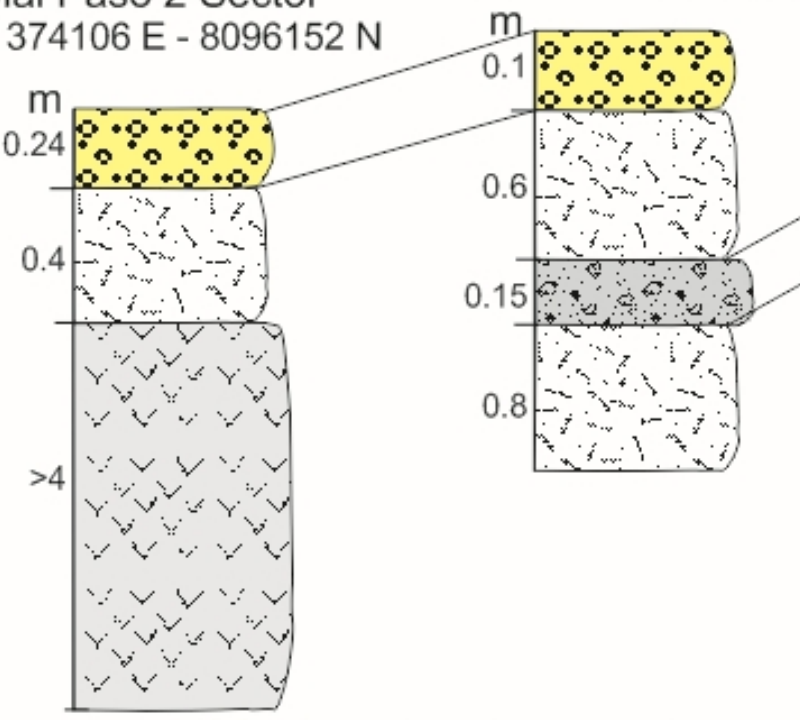

Pumice fall deposit dated at 3,085 \pm 35 BP.

U. Upper Halloween scoria fall deposit Parda scoria fall deposit

Lower Halloween scoria fall deposit

$\because: \%$ Callazas ignimbrite deposit

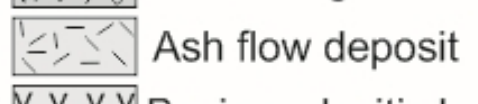

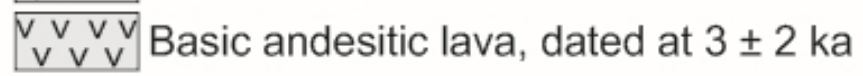
Lahar deposit

Hyperconcentrated flow deposit

Ash or pumice fall reworked

Mal Paso1 Sector

UTM 374875 E - 8097148 N

Hualtavira Sector UTM 376317 E - $8095281 \mathrm{~N}$

$>1.0$

0.2
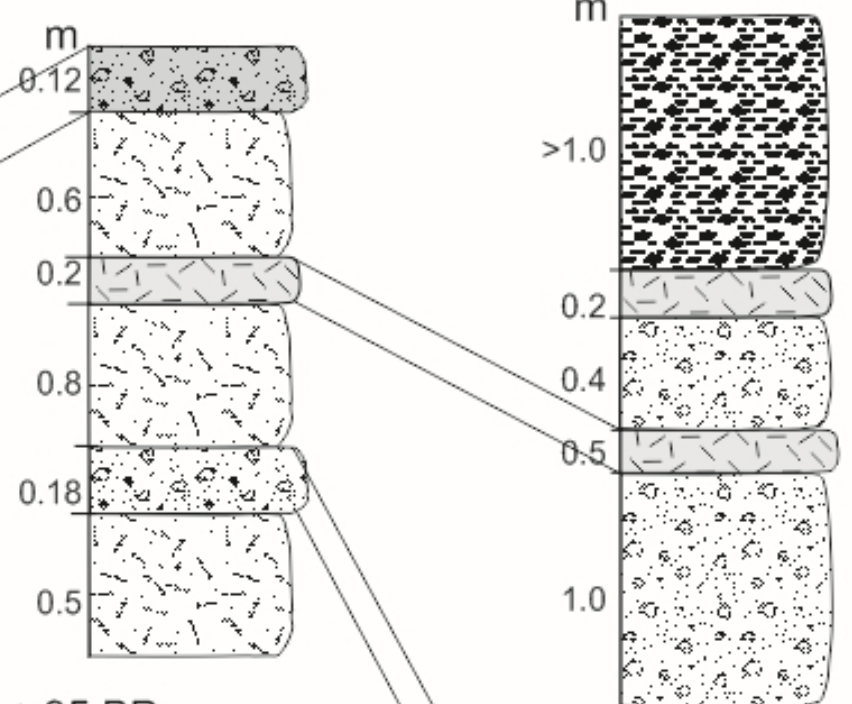

0.5

5

1.0

$\left[\begin{array}{c}0 \\ 0\end{array}\right.$

0.18

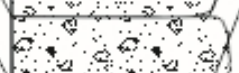

o

3.0

a

क

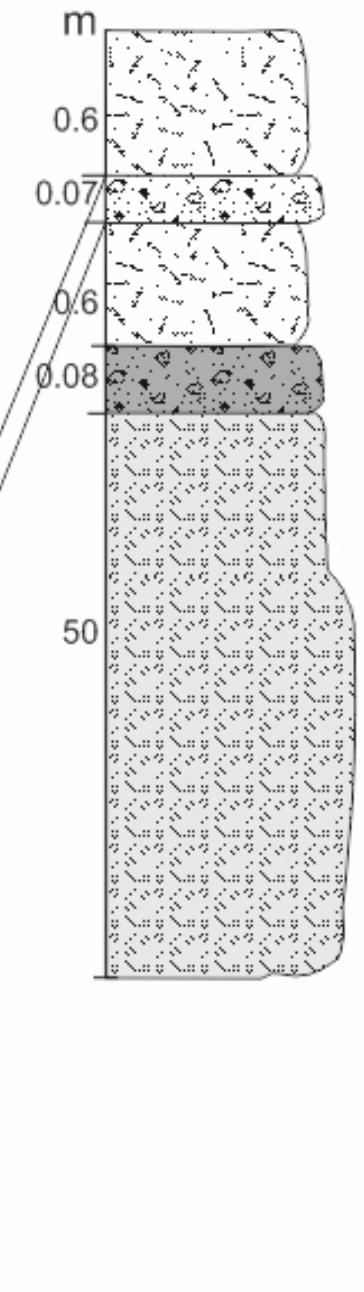




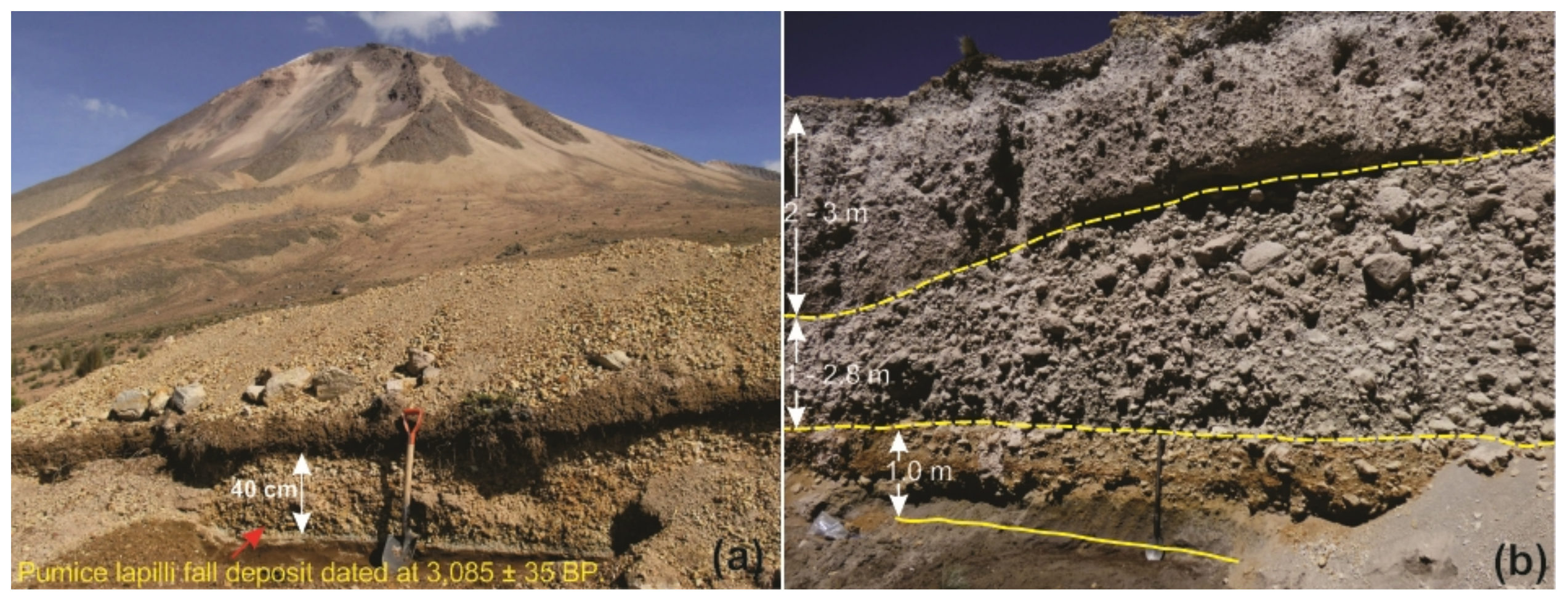




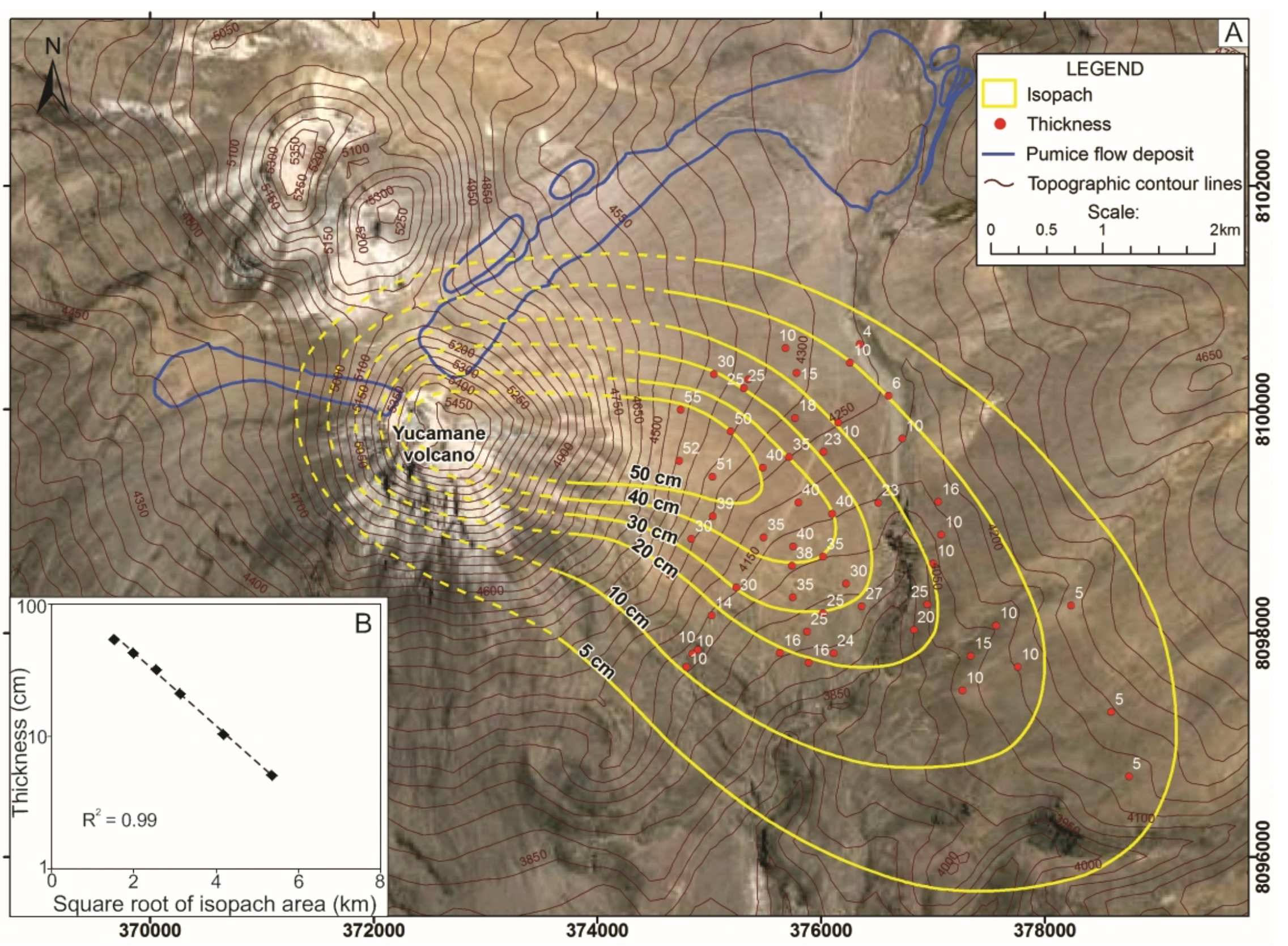



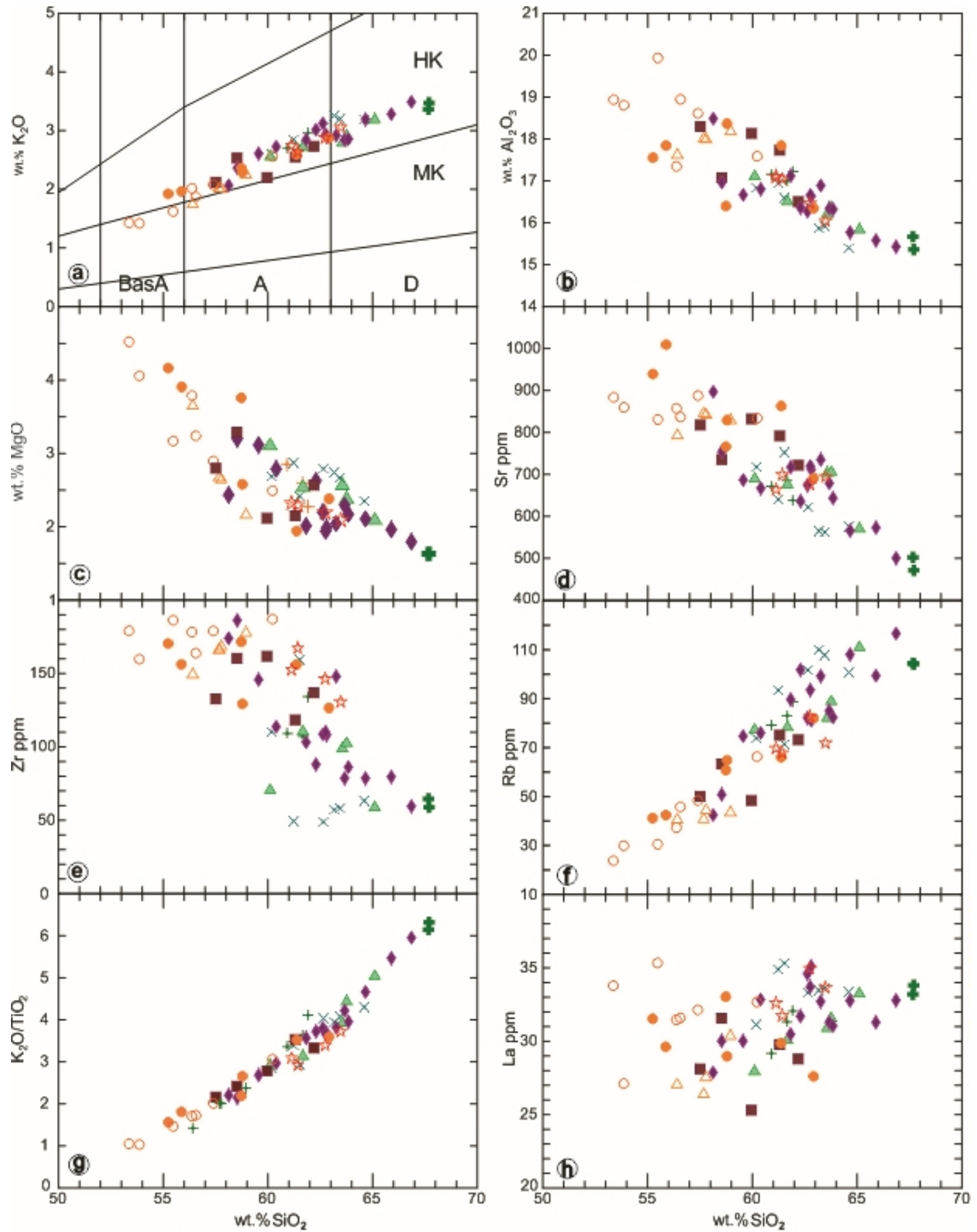

\begin{tabular}{|c|c|c|}
\hline $\begin{array}{l}\text { Calientes I } \\
\text { [Calientes II } \\
\text { [X]Calientes III } \\
\text { BCalientes IV }\end{array}$ & $\begin{array}{l}\text { E Yucamane I } \\
\text { Yucamane II } \\
\text { Yucamane III }\end{array}$ & $\begin{array}{l}\text { DLava flows } \\
\text { Scoria flow deposits } \\
\text { Scoria fall deposits } \\
\text { S. Lapilli fall deposit dated at 3,085 BP }\end{array}$ \\
\hline
\end{tabular}




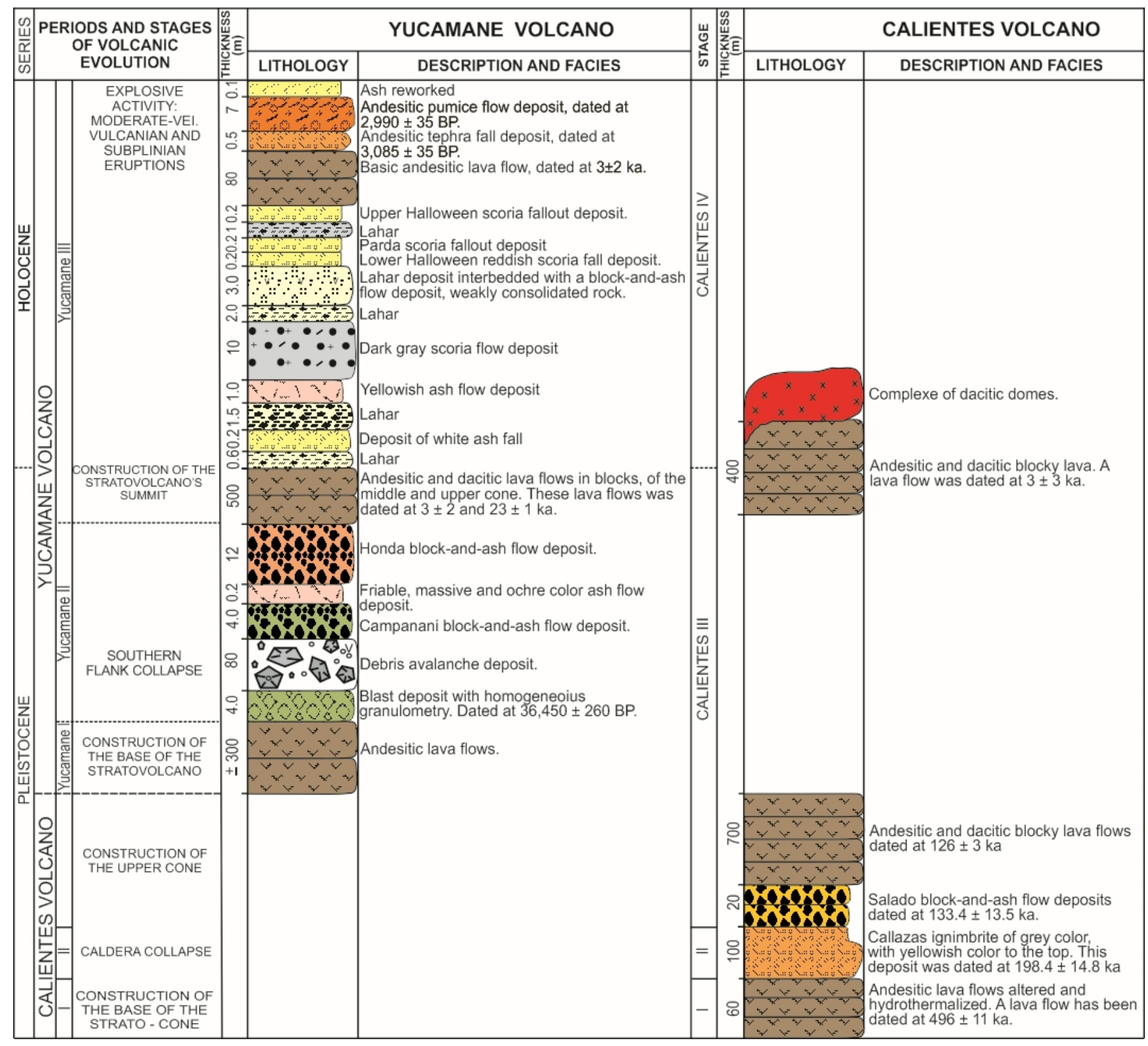



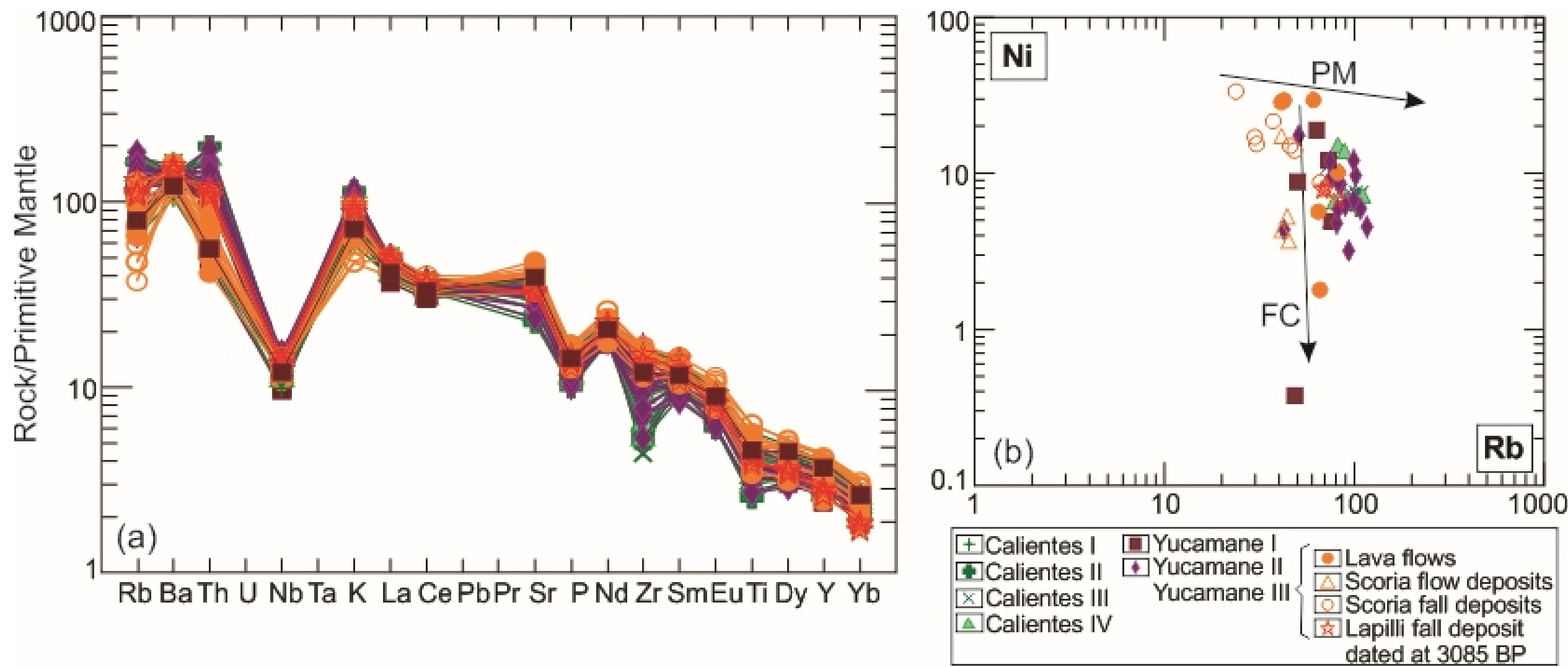


\section{Supplementary material 1}

The eruptive chronology of the Yucamane-Calientes compound volcano: a potentially active edifice of the Central Andes (Southern Peru)

\section{Description of methods}

\section{Major and trace element whole-rock data}

Major and trace element were determined at the Institut Universitaire Européen de la Mer (Brest, France), following the analytical procedure of Cotten et al. (1995). Typically $250 \mathrm{mg}$ of rock power were dissolved in closed screw-top teflon vessels (Savillex) at about $90^{\circ} \mathrm{C}$ for one day using $3 \mathrm{ml}$ of concentrated $\mathrm{HF}$, and $1 \mathrm{ml}$ of concentrated $\mathrm{HNO}_{3}$. Next, $96 \mathrm{ml}$ of $\mathrm{H}_{3} \mathrm{BO}_{3}$ aqueous solution ( $20 \mathrm{~g} / \mathrm{L} \mathrm{H}_{3} \mathrm{BO}_{3}$ ) were added to neutralize the excess HF. All reagents used are analytical grade. Elements were measured by inductively coupled plasma-atomic emission spectrometry (ICP-AES) using a Horiba Jobin Yvon ${ }^{\circledR}$ Ultima 2 spectrometer. The boron included in the solution was used as an internal standard. Calibrations were made using international standard, ACE, ME, WSE, JB2. For major elements, relative standard deviation is $\leq 1 \%$ for $\mathrm{SiO}_{2}$ and $\leq 2 \%$ for the other major elements, for trace elements standard deviation is $\leq 5 \%$.

\section{${ }^{40} \mathrm{~K}-{ }^{40}$ Ar geochronology}

After macroscopic and microscopic inspections, groundmass from fresh samples was prepared following methods detailed in Guillou et al. (1998). The groundmass is assumed to have formed shortly after eruption and is unlikely to contain any significant excess argon. All the samples were crushed and sieved to $0.250-0.125 \mathrm{~mm}$ size fractions and ultrasonically washed in acetic acid $(1 \mathrm{~N})$ during 45 minutes at a temperature of $60^{\circ} \mathrm{C}$, to remove any secondary mineral phases that might be present in minute 
amounts. Phenocrysts which are potential carriers of extraneous ${ }^{40} \mathrm{Ar}$ (including excess and inherited components) were filtered out using magnetic, gravimetric, and visual hand picking separation.

The isotopic composition and abundance of Ar were determined using an unspiked technique described by Charbit et al. (1998). In the unspiked technique, argon extracted from the sample is measured in sequence with purified aliquots of atmospheric argon at comparable working gas pressure in the mass-spectrometer, to suppress mass discrimination effects between the atmospheric reference and the unknown. This approach allows young samples to be dated reliably, as demonstrated via direct comparisons with the ${ }^{40} \mathrm{Ar} /{ }^{39} \mathrm{Ar}$ dating method (Guillou et al., 2004; Guillou et al., 2011; Singer et al., 2008; Singer et al., 2014). Aliquots of groundmass were separated by means of densitometric and magnetic separations following the procedure described in Guillou et al. (1998). Determination of K was carried out at the CRPG (Nancy, France) by atomic absorption (flame photometry) with a relative precision of 1\%. Argon was extracted by radio frequency heating of $0.5-2.0 \mathrm{~g}$ of sample, then transferred to an ultra-high-vacuum glass line and purified with titanium sponge and ZrAr getters. Isotopic analysis was performed on total ${ }^{40} \mathrm{Ar}$ contents ranging between 1.0 and $5.9 \times 10^{-11}$ moles using a $180^{\circ}, 6 \mathrm{~cm}$ radius mass spectrometer with an accelerating potential of $620 \mathrm{~V}$. The mass spectrometer sensitivity is $5.2 \times 10^{-1} \mathrm{~mol} / \mathrm{A} @ \mathrm{~m} / \mathrm{e}=40$ with amplifier backgrounds of $5 \times 10^{-14} \mathrm{~A} @ \mathrm{~m} / \mathrm{e}=40$ and $1.0 \times 10^{-15} \mathrm{~A} @ \mathrm{~m} / \mathrm{e}=36$. Beam sizes were measured simultaneously on a double Faraday collector in sets of 100 on-line acquisitions with a $1 \mathrm{~s}$ integration time, using two Keithley Model 6514 System Electrometers. A manometrically calibrated dose of atmospheric argon (cal. Dose) is used to convert beam intensities into atomic abundances. This dose, when comparable in pressure with the unknown, or a separate measurement of atmospheric argon (atm. 
Ref.) is used to monitor the atmospheric correction. The manometric calibration is based on periodic, replicate determinations of international dating standards of known K-Ar age using the same procedure for the unknown samples to be measured, as described in Charbit et al. (1998). This allows the total ${ }^{40} \mathrm{Ar}$ content of the sample to be determined with a precision of about \pm 0.2\% $(2 \sigma)$. Standards used include LP-6 (127.8 \pm 0.7 Ma, Odin et al., 1982) and HD-B1 (24.21 \pm 0.32 Ma, Fuhrmann et al., 1987; Hess and Lippolt, 1984; Hautmann and Lippolt, 2000). At the 95\% confidence level, the values adopted here are consistent with those obtained for several ${ }^{40} \mathrm{Ar} /{ }^{39} \mathrm{Ar}$ standards through the intercalibration against biotite GA-1550 by Renne et al. (1998) and Spell and McDougall (2003). Uncertainties for the $\mathrm{K}$ and Ar data are $1 \sigma$ analytical only, and consist of propagated and quadratically averaged experimental uncertainties arising from the $\mathrm{K},{ }^{40} \mathrm{Ar}$ (total), and ${ }^{40} \mathrm{Ar} *$ determinations. Uncertainties on the ages are given at $2 \sigma$.

\section{${ }^{40} \mathrm{Ar}-{ }^{39} \mathrm{Ar}$ geochronology}

Samples were crushed and sieved to the $400 \mu \mathrm{m}-250 \mu \mathrm{m}$ fraction size. After ultrasonic cleaning in acetic acid $(1 \mathrm{~N})$ for 45 minutes at a temperature of $60^{\circ} \mathrm{C}$, feldspars were concentrated through several density separations using Lithium Meta Tungstate (LMT) heavy liquid. Pristine feldspars crystals ranging from $250 \mu \mathrm{m}$ up to $400 \mu \mathrm{m}$ were handpicked under a binocular microscope and then slightly leached for 5 min in a $7 \%$ HF acid solution in order to remove adhered groundmass. A total of about 50 grains were finally handpicked and available for ${ }^{40} \mathrm{Ar}-{ }^{39} \mathrm{Ar}$ laser total fusion experiments. Feldspars were irradiated in the CLICIT facility at the Oregon State University TRIGA reactor for 120 minutes (Irr\#CO001) or 60 minutes (Irr\#CO003). After irradiation, crystals were transferred into a copper sample holder and then loaded 
into a differential vacuum Cleartran window. Prior to the fusion, all crystals were degassed at $4 \%$ of the laser power to remove potential atmospheric component that could be found at the surface and/or in the feldspar fractures. For each experiment, a crystal was molten using a focused 25 W CO2 laser (Synrad) at about 10\% of the full laser power. Extracted gas was purified by two GP-50 getter pumps one operating at $250^{\circ} \mathrm{C}$, the second being at room temperature. The purified gas is then measured using a high-sensitivity noble gas GV5400 instrument operated in ion counting mode.

Neutron fluence (J) was monitored by co-irradiation of ACs-2 crystals (Nomade et al., 2005) placed in three pits encircling the sample. 2 ACs-2 crystal of each pit were analyzed and the $\mathrm{J}$ value was the arithmetic average of these 6 single crystal laser fusion analyses. It is reported in Supplementary Tables 2 along with the correction factors for interfering neutron reactions. Corresponding $\mathrm{J}$ values were calculated using an age of $1.1891 \pm 0.0008$ Ma (Niespolo et al., 2017). The total decay constants of Renne et al (2010, 2011) and the ${ }^{40} \mathrm{Ar} /{ }^{36} \mathrm{Ar}$ atmospheric ratio at 298.56 (Lee et al., 2006) were used for age calculations. The precision and accuracy of the mass discrimination correction was monitored by periodical measurements of air argon. This monitoring is performed using a dedicated air-calibration system featuring a 6 liters tank filled with purified atmospheric argon. This tank is connected to the mass spectrometer vacuum line via two pneumatically- actuated air pipettes of approximately 0.1 and 1.0 cc. This system allows for a 1 cc and a 0.1 cc atmospheric aliquots to be delivered into the mass spectrometer and permits a careful monitoring of the mass discrimination over a wide dynamic range with a precision better than $0.15 \%$ (2б; standard deviation for multiples of experiments) for any given bean size measured.

\section{U-Pb geochronology}


Zircons were separated at the Laboratoire Magmas and Volcans (LMV Clermont-Ferrand, France) using standard techniques of crushing and sieving, followed by Wilfley table, magnetic separation and heavy liquids before handpicking under binocular microscope. They were mounted in epoxy disks and ground and polished at $0.25 \mu \mathrm{m}$ to expose crystal interiors. U-Th-Pb isotopic data on zircons were obtained by laser ablation inductively coupled plasma spectrometry (LA-ICP-MS) at the LMV and reported in Supplementary Material 3. The analyses involved the ablation of minerals with a Resonetics M-50 excimer laser system operating at a wavelength of $193 \mathrm{~nm}$. Spot diameters of $60 \mu \mathrm{m}$ were associated to repetition rates of $4 \mathrm{~Hz}$ and fluency of $3.0 \mathrm{~J} / \mathrm{cm} 2$. The ablated material was carried into helium and then mixed with nitrogen and argon before injection into the plasma source of a Thermo Element XR Sector Field ICP-MS. The alignment of the instrument and mass calibration were performed before every analytical session using the NIST SRM 612 reference glass, by inspecting the signals of 238U, 232Th and 208Pb and by minimising the $\mathrm{ThO}+/ \mathrm{Th}+$ ratio. The analytical method for isotope dating with laser ablation is basically similar to that reported in Paquette et al. (2014) and adapted to the analysis of Pliocene-Pleistocene zircons (Paquette et al., 2019). The $235 \mathrm{U}$ signal is calculated from $238 \mathrm{U}$ on the basis of the ratio $238 \mathrm{U} / 235 \mathrm{U}=$ 137.818 (Hiess et al., 2012). Single analyses consisted of 30 seconds of background integration with laser off followed by 1 minute integration with the laser firing.

Data are corrected for $\mathrm{U}-\mathrm{Pb}$ fractionation and for instrumental mass bias by standard bracketing with repeated measurements of GJ-1 zircon standard (Jackson et al., 2004). Repeated analyses of 91500 zircon reference material (Wiedenbeck et al., 1995) during each analytical session and treated as unknown, independently control the reproducibility and accuracy of the corrections. Data reduction was carried out with the software package GLITTER ${ }^{\circledR}$ from Macquarie Research Ltd (van Achterbergh et al., 
2001; Jackson et al., 2004). Common $\mathrm{Pb}$ and initial disequilibria caused by ${ }^{230} \mathrm{Th}^{/ 238} \mathrm{U}$ and ${ }^{231} \mathrm{~Pa} /{ }^{235} \mathrm{U}$ fractionation in the zircon/melt system were corrected according to Sakata et al. (2017) and Sakata (2018) method and related Microsoft Excel ${ }^{\circledR}$ spreadsheet. The concentrations in $\mathrm{U}-\mathrm{Th}-\mathrm{Pb}$ were calibrated relative to the certified contents of GJ-1 zircon (Jackson et al., 2004) reference material. The available fractionation factor of $\mathrm{Pa} / \mathrm{U}$ in a zircon-melt system of rhyolitic composition roughly shows agreement with a value of $2.9 \pm 1.0$ (Sakata, 2018). This value and related uncertainty is propagated into the calculations. Weighted mean ${ }^{206} \mathrm{~Pb} /{ }^{238} \mathrm{U}$ ages were generated using Isoplot/Ex v. 2.49 software package by Ludwig (2001).

\section{${ }^{14}$ C geochronology}

Before ${ }^{14} \mathrm{C}$ measurement, samples were examined under a binocular microscope with the aim of eliminating any potential contaminant such as sand and roots. Then, the samples were chemically pre-treated to remove contaminants, in order to isolate a suitable fraction for dating. The treatment (referred to as the "AAA" treatment) consists of the following steps: (1) acid ( $\mathrm{HCl})$ leaching to remove soil carbonate; (2) alkali $(\mathrm{NaOH})$ leaching to remove humic acids; and, (3) acid (HCl) leaching to remove any "modern" $\mathrm{CO}_{2}$ absorbed during the previous steps. Variable amounts of the dried sample were used to obtain, after combustion, a $\mathrm{CO}_{2}$ volume equivalent to at least $1 \mathrm{mg}$ of $\mathrm{C}$. Then, $\mathrm{CO}_{2}$ is reduced by $\mathrm{H}_{2}$ in the presence of iron powder. ${ }^{14} \mathrm{C}$ activity is finally measured by mass spectrometry. The ${ }^{14} \mathrm{C}$ ages are calculated following the procedure of Mook and van der Plicht (1999) and corrected for mass dependent effects (isotope fractionation) using the measured ${ }^{13} \mathrm{C} /{ }^{12} \mathrm{C}$ ratio. This $\delta^{13} \mathrm{C}$ includes the fractionation which occurred both during sample preparation and measurement. 


\section{References}

Charbit, S., Guillou, H., Turpin, L., 1998. Cross calibration of K-Ar standard minerals using an unspiked Ar measurement technique. Chemical Geology 150, 147-159.

Cotten, J., Le Dez, A., Bau, M., Caroff, M., Maury, R.C., Dulski, P., Fourcade, S., Bohn, M., Brousse, R., 1995. Origin of anomalous rare-earth element and Yttrium enrichments in subaerial exposed basalts: evidence from French Polynesia. Chemical Geology 119, 115-138.

Fuhrmann, U., Lippolt, H., Hess, J.C., 1987. HD-B1 Biotite reference material for K-Ar chronometry. Chemical Geology 66, 41-51.

Guillou, H., Carracedo, J.C., Day, S., 1998. Dating of the upper Pleistocene - Holocene volcanic activity of La Palma using the Unspiked K-Ar Technique. Journal of Volcanology and Geothermal Research 86, 137-149.

Guillou, H., Singer, B. Laj, C., Kissel, C., Scaillet, S., Jicha, B.R., 2004. On the age of the Laschamp geomagnetic event. Earth and Planetary Sciences Letters 227, 331343.

Guillou, H., Nomade, S., Carracedo, J.C., Kissel, C., Laj, C., Perez Torrado, F.J., Wandres, C., 2011. Effectiveness of combined Unspiked K-Ar and ${ }^{40} \mathrm{Ar} /{ }^{39} \mathrm{Ar}$ dating methods in the ${ }^{14} \mathrm{C}$ age range. Quaternary Geochronology 6, 530-538.

Hautmann, H.J., Lippolt, H.J., 2000. ${ }^{40} \mathrm{Ar} /{ }^{39} \mathrm{Ar}$ dating of central European K-Mn oxides, a chronological framework of supergene alteration processes during the Neogene. Chemical Geology 170, 37-80.

Hess, J.C., Lippolt, H.J., 1994. Compilation of K-Ar measurements on HD-B1 standard biotite. In: Odin, G.S. (Ed.), Phanerozoic Time Scale Bull. Liais. Inform. I.U.G.S., Subcom. Geochronol. vol. 12, pp. 19-23. 
Hiess, J., Condon, D.J., McLean, N., Noble, S.R., 2012. 238U/235U systematics in terrestrial uranium-bearing minerals. Science 335, 1610-1614.

Jackson, S.E., Pearson, N.J., Griffin, W.L., Belousova, E.A., 2004. The application of laser ablation-inductively coupled plasma-mass spectrometry to in situ U-Pb zircon geochronology. Chem. Geol. 211, 47-69.

Lee, J. Y., Marti, K., Severinghaus, K., Kawamura, K., Yoo, H.S., Lee, J.B., Kim J.S., 2006. A redetermination of the isotopic abundances of atmospheric Ar, Geochimica et Cosmochimica Acta 70, 4507-4512.

Ludwig, K.R., 2001. User's manual for Isoplot/Ex Version 2.49, a Geochronological Toolkit for Microsoft EXCEL. Berkeley Geochronological Center, Special Publication 1a, Berkeley, USA (55 pp).

Mook, W.G, van der Plicht, J., 1999. Reporting 14C activities and concentrations. Radiocarbon 41, 227-239.

Niespolo, E.M, Rutte, D., Deino, A.L., Renne, P.R., 2017. Intercalibration and age of the Alder Creek sanidine ${ }^{40} \mathrm{Ar} /{ }^{39} \mathrm{Ar}$ standard. Quaternary Geochronology. 39, 205213.

Nomade, S., Renne, P.R., Vogel, N., Deino, A.L., Sharp, W.D., Becker, T.A., Jaouni, A.R., Mundil, R., 2005. Alder creek sanidine (ACs-2): a quaternary ${ }^{40} \mathrm{Ar} /{ }^{39} \mathrm{Ar}$ dating standard tied to the Cobb mountain geomagnetic event. Chem. Geol. 218, 315-338.

Odin, G.S. (Ed.), 1982. Numerical Dating in Stratigraphy. Wiley, Chichester, 2 vols, 1094 pp.

Paquette, J.-L., Piro, J.-L., Devidal, J.-L., Bosse, V., Didier, A., Sannac, S., and Abdelnour, Y., 2014. Sensitivity Enhancement in LA-ICP-MS by N2 Addition to Carrier Gas: Application to Radiometric Dating of U-Th-Bearing Minerals. Agilent ICP-MS J., 58, 4-5.

Paquette, J.L., Médard, E., Francomme, J., Bachèlery, P., Hénot, J.M., 2019. LA-ICP$\mathrm{MS} \mathrm{U} / \mathrm{Pb}$ zircon timescale constraints of the Pleistocene latest magmatic activity in the Sancy stratovolcano (French Massif Central). Journal of Volcanology and Geothermal Research 374, 52-61. 
Renne, P.R., Swisher, C.C., Deino, A.L., Karner, D.B., Owens, T.L., DePaolo, D.J., 1998. Intercalibration of standards, absolute ages and uncertainties in ${ }^{40} \mathrm{Ar} /{ }^{39} \mathrm{Ar}$ dating. Chemical Geology 145, 117-152.

Renne, P.R., Mundil, R., Balco, G., Min, K., Ludwig, K.R., 2010. Joint determination of ${ }^{40} \mathrm{~K}$ decay constants and ${ }^{40} \mathrm{Ar} * /{ }^{40} \mathrm{~K}$ for the Fish Canyon sanidine standard, and improved accuracy for ${ }^{40} \mathrm{Ar} /{ }^{39} \mathrm{Ar}$ geochronology. Geochimica et Cosmochimica Acta, 74, 5349-5367.

Renne, P.R., Balco, G., Ludwig, K.R., Mundil, R., Min, K., 2011. Response to the comment by W.H. Schwarz et al. on " Joint determination of ${ }^{40} \mathrm{~K}$ decay constants and ${ }^{40} \mathrm{Ar}{ }^{*} /{ }^{40} \mathrm{~K}$ for the Fish Canyon sanidine standard, and improved accuracy for ${ }^{40} \mathrm{Ar} /$ ${ }^{39} \mathrm{Ar}$ geochronology" by P.R. Renne et al. (2010). Geochimica et Cosmochimica Acta, 75 (17), 5097-5100.

Sakata, S., 2018. A practical method for calculating the U-Pb age of Quaternary zircon: Corrections for common $\mathrm{Pb}$ and initial disequilibria. Geochemical Journal, 52, 281286.

Sakata, S., Hirakawa, S., Iwano, H., Danhara, T., Guillong, M., Hirata, T., 2017. A new approach for constraining the magnitude of initial disequilibrium in Quaternary zircons by coupled uranium and thorium decay series dating. Quaternary Geochronology, 37, 1-12.

Singer, B.S., Hoffman, K.A., Schnepp, E., Guillou, H., 2008. Multiple Brunhes Chron excursions recorded in the West Eifel (Germany) volcanics: Support for long-held mantle control over the non-axial dipole field. Physics of the Earth and Planetary Interiors 169, 28-40.

Singer, B.S., Guillou, H., Jicha, B.R., Zanella, E., Camps, P., 2014. Refining the Quaternary Geomagnetic Instability Time Scale (GITS): Lava flow recordings of the Blake and Post-Blake excursions. Quaternary Geochronology 21, 16-28.

Spell, T.L., McDougall, I., 2003. Characterization and calibration of ${ }^{40} \mathrm{Ar} /{ }^{39} \mathrm{Ar}$ dating standards. Chemical Geology 198, 189-211.

Van Achterbergh, E., Ryan, C.G., Jackson, S.E., Griffin, W.L., 2001. Data reduction software for LA-ICP-MS. In: Sylvester, P. (Ed.), Laser Ablation-ICPMS in the Earth Science. 29. Mineralogical Association of Canada, pp. 239-243. 
Wiedenbeck, M., Allé, P., Corfu, F., Griffin, W.I., Meier, M., Oberli, F., Quadt, A.V., Roddick, J., Spiegel, W., 1995. Three natural zircon standards for U-Th-Pb, Lu-Hf, trace element and REE analyses. Geostandards Newsletter, 19, 1-23. 